\title{
Ideological Voting on Federal Courts of Appeals: A Preliminary Investigation
}

\section{Citation}

Cass R. Sunstein, Lisa Michelle Ellman \& David Schkade, Ideological Voting on Federal Courts of Appeals: A Preliminary Investigation (John M. Olin Program in Law \& Economics Working Paper No. 198, 2003).

\section{Published Version}

http://chicagounbound.uchicago.edu/law_and_economics/247/

\section{Permanent link}

http://nrs.harvard.edu/urn-3:HUL.InstRepos:12876717

\section{Terms of Use}

This article was downloaded from Harvard University's DASH repository, and is made available under the terms and conditions applicable to Other Posted Material, as set forth at http:// nrs.harvard.edu/urn-3:HUL.InstRepos:dash.current.terms-of-use\#LAA

\section{Share Your Story}

The Harvard community has made this article openly available.

Please share how this access benefits you. Submit a story.

Accessibility 


\section{University of Chicago Law School Chicago Unbound}

Coase-Sandor Working Paper Series in Law and

Economics

Coase-Sandor Institute for Law and Economics

2003

\section{Ideological Voting on Federal Courts of Appeals: A Preliminary Investigation}

Cass R. Sunstein

Lisa Michelle Ellman

David Schkade

Follow this and additional works at: http://chicagounbound.uchicago.edu/law_and_economics Part of the Law Commons

\section{Recommended Citation}

Cass R. Sunstein, Lisa Michelle Ellman \& David Schkade, "Ideological Voting on Federal Courts of Appeals: A Preliminary Investigation" (John M. Olin Program in Law and Economics Working Paper No. 198, 2003).

This Working Paper is brought to you for free and open access by the Coase-Sandor Institute for Law and Economics at Chicago Unbound. It has been accepted for inclusion in Coase-Sandor Working Paper Series in Law and Economics by an authorized administrator of Chicago Unbound. For more information, please contact unbound@law.uchicago.edu. 


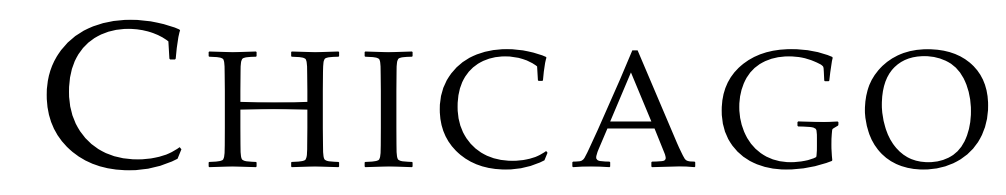

JOHN M. OLIN LAW \& ECONOMICS WORKING PAPER NO. 198 (2D SERIES)

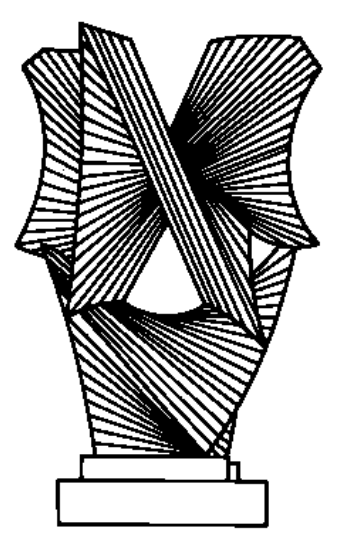

Ideological Voting on Federal Courts of Appeals: A Preliminary Investigation

Cass R. Sunstein, David Schkade, and Lisa Michelle Ellman

\author{
THE LAW SCHOOL \\ THE UNIVERSITY OF CHICAGO
}

September 2003

This paper can be downloaded without charge at:

The Chicago Working Paper Series Index: http://www.law.uchicago.edu/Lawecon/index.html and at the Social Science Research Network Electronic Paper Collection:

http://ssrn.com/abstract_id= 
Preliminary draft 9/1/2003

All rights reserved

\title{
Ideological Voting on Federal Courts of Appeals: A Preliminary Investigation
}

\author{
Cass R. Sunstein," David Schkade, ${ }^{* * *}$ and Lisa Michelle Ellman ${ }^{* * *}$
}

\begin{abstract}
For many decades, the United States has been conducting an extraordinary natural experiment: Randomly assigned three-judge panels on courts of appeals produce extensive evidence of the effect of judicial ideology on judges'votes. If the political party of the appointing president is treated as a rough proxy for ideology, then it becomes possible to test three hypotheses: (a) a judge's votes, in ideologically contested areas, can be predicted by the party of the appointing president; (b) a judge's ideological tendency, in such areas, will be amplified if the panel has two other judges appointed by an appointing president of the same political party; and (c) a judge's ideological tendency, in such areas, will be dampened if the panel has no other judge appointed by an appointing president of the same political party. All three hypotheses are confirmed in many areas, including affirmative action, campaign finance, sex discrimination, sexual harassment, piercing the corporate veil, disability discrimination, race discrimination, and review of environmental regulations. An important implication is that panel composition has a strong effect on likely outcomes, thus creating extremely serious problems for the rule of law. Taken as a whole, the evidence suggests that judges frequently issue collegial concurrences, that is, concurrences produced by the unanimous views of the other judges on the panel, and that judges are subject to group polarization, by which groups of like-minded people go to extremes. Notably, all three hypotheses are rejected in the areas of federalism, criminal appeals, and takings of private property, because Republican and Democratic appointees vote essentially alike. In the areas of abortion and capital punishment, the first hypothesis is confirmed, but the second and third are rejected, because judges vote their convictions, and are not affected by the composition of the panel. Disaggregating the data by circuit allows courts of appeals to be ranked along an ideological spectrum; it also shows striking differences between Republican appointees and Democratic appointees on different circuits. Normative implications are briefly explored.

\footnotetext{
* Karl N. Llewellyn Distinguished Service Professor, Law School and Department of Political Science, University of Chicago.

${ }^{* *}$ Herbert D. Kelleher Regents Professor of Business, University of Texas, Austin.

${ }^{* * *}$ Third-year law student, University of Chicago. We are grateful to comments from Matthew Adler, Frank H. Easterbrook, Robert Hahn, Sendhil Mullainathan, Eric A. Posner, Richard A. Posner, and Richard Thaler. We are also grateful to participants in workshops at the University of Chicago Law School and the University of Chicago Business School. Caryn Campbell provided superb research assistance.
} 
Over many decades, the United States has been conducting an extraordinary natural experiment with respect to the performance of federal judges. The experiment involves the relationship between political ideology ${ }^{2}$ and judicial decisions. Many people believe that political ideology should not and generally does not affect legal judgments, ${ }^{3}$ and this belief contains some truth. Frequently the law is clear and judges should and will simply implement it, whatever their political commitments. But what happens when the law is unclear? What role does ideology play then?

It is extremely difficult to investigate these questions directly. But it is possible to identify a proxy for political ideology: The political affiliation of the appointing president. Presidents are frequently interested in ensuring that judicial appointees are of a certain stripe. A Democratic president is unlikely to want to appoint judges who will seek to overrule Roe v. Wade ${ }^{4}$ and strike down affirmative action programs. A Republican president is unlikely to want to appoint judges who will understand the Constitution to require states to recognize same-sex marriages. It is reasonable to hypothesize that as a statistical regularity, judges appointed by Republican presidents (hereinafter described, for ease of exposition, as Republican appointees) will be more conservative than judges appointed by Democratic presidents (Democratic appointees, as we shall henceforth call them). But is this hypothesis true? When is it true, and to what degree is it true?

More subtly, we might speculate that federal judges are subject to panel effects that on a three-judge panel, a judge's likely vote is affected by whether she is sitting with no, one, or two judges appointed by presidents of the same political party. On this view, a Republican appointee, sitting with two Democratic appointees, is more likely to vote as Democratic appointees typically do, whereas a Democratic appointee, sitting with two Republican appointees, is more likely to vote as Republican appointees typically do. But is this in fact the usual pattern? The invariable one? Since judges in a given circuit are assigned to panels (and therefore to cases) randomly, the existence of a large data set allows these issues to be investigated empirically.

In this Essay, we examine a subset of possible case types, focusing on a number of controversial issues that seemed especially likely to reveal divisions between Republican and Democratic appointees. In brief, we explore cases involving abortion, affirmative action, campaign finance, capital punishment, commerce clause challenges to congressional enactments, the contracts clause, criminal appeals, disability discrimination, industry challenges to environmental regulation, piercing the corporate veil, race discrimination, sex discrimination, and claimed takings of private property without just compensation. We offer a more detailed description of our subjects and methods below.

More specifically, the central purpose of this Essay is to examine three central

\footnotetext{
${ }^{2}$ In using this term, we do not intend to venture anything especially controversial about the actual or appropriate grounds of judicial decisions. As will be clear, we measure "ideology" by the political affiliation of the appointing president.

${ }^{3}$ See Jeffrey Rosen, Obstruction of Judges, New York Times Magazine, August 11, 2002, at 38.

${ }^{4} 410$ U.S. 113 (1973).
} 
hypotheses:

1. Ideological voting. On issues with a strong ideological flavor, Republican appointees vote very differently from Democratic appointees. Such issues include many of those just mentioned, such as affirmation action, campaign finance, federalism, the rights of criminal defendants, sex discrimination, piercing the corporate veil, racial discrimination, property rights, capital punishment, disability discrimination, sexual harassment, and abortion.

2. Ideological dampening. A judge's ideological tendency, in such cases, is likely to be dampened if she is sitting with two judges from a different political party. For example, a Democratic appointee should be less likely to vote in a stereotypically liberal fashion ${ }^{5}$ if accompanied by two Republican appointees, and a Republican appointee should be less likely to vote in a stereotypically conservative fashion if accompanied by two Democratic appointees.

3. Ideological amplification. A judge's ideological tendency, in such cases, is likely to be amplified if she is sitting with two judges from the same political party. A Democratic appointee should show an increased tendency to vote in a stereotypically liberal fashion if accompanied by two Democratic appointees, and a Republican appointee should be more likely to vote in a stereotypically conservative fashion if accompanied by two Republican appointees.

We find that in numerous areas of the law, all three hypotheses are strongly confirmed. Each finds support in federal cases involving campaign finance, affirmative action, sex discrimination, sexual harassment, piercing the corporate veil, racial discrimination, disability discrimination, contract clause violations, and review of environmental regulations. In such cases, the aggregate data strongly confirm all three hypotheses. Indeed, we find many extreme cases of ideological dampening, which we might call leveling effects, in which party differences are wiped out. With leveling effects, Democratic appointees, when sitting with two Republican appointees, are as likely to vote in the stereotypically conservative fashion as are Republican appointees, when sitting with two Democratic appointees. We also find strong amplification effects, such that if the data set in the relevant cases is taken as a whole, Democratic appointees, sitting with two Democratic appointees, are about twice as likely to vote in the stereotypically liberal fashion as are Republican appointees, sitting with two Republican appointees - a far larger disparity than the disparity between Democratic and Republican votes when either is sitting with one Democratic appointee and one Republican appointee. In most of the areas investigated here, the political party of the appointing president is a fairly good predictor of how an individual judge will vote. But in those same areas, the political party of the president who appointed the other two judges on the panel is at least as good a predictor of how individual judges will vote. All in all,

\footnotetext{
${ }^{5}$ We use this phrase throughout for the purpose of simplicity. Of course, no sensible stereotype predicts that Republican appointees will always vote against sex discrimination plaintiffs or in favor of challenges to affirmative action programs.
} 
Democratic appointees show somewhat greater susceptibility to panel effects than do Republican appointees.

But there are noteworthy counterexamples. In three important areas, ideology does not predict judicial votes, and hence all three hypotheses are refuted. This is the pattern in criminal appeals, takings claims, and commerce clause challenges to congressional enactments. And in two areas, the first hypothesis is supported, but the second and third hypotheses are refuted. These two areas are abortion and capital punishment. In these areas, judges apparently vote their convictions, and are not affected by panel composition.

We offer a number of other findings. We show that variation in panel composition leads to dramatically different outcomes, in a way that creates serious problem for the rule of law. In the cases we analyze, a panel composed of three Democratic appointees issues a liberal ruling $61 \%$ of the time, whereas a panel composed of three Republican appointees issues a liberal ruling only $34 \%$ of the time. A panel composed of two Republican appointees and one Democrat issues a liberal ruling 39\% of the time; a panel composed of two Democratic appointees and one Republican does so 50\% of the time. These differences do not show that the likely result is foreordained by the composition of the panel. But the plaintiff's chances, in the cases we examine, are much affected by the luck of the draw. One of the noteworthy points about these numbers is that a Democratic majority, or a Republican majority, has the votes to do what it wishes. Apparently a large disciplining effect comes from the presence of a single panelist from another party. Hence all-Republican panels show far more conservative patterns than majority Republican panels, and all-Democratic panels show far more liberal patterns than majority Democratic panels.

Disaggregating our data, we provide evidence of how ideology varies by circuit, showing that the Ninth and Second Circuits are the most liberal, while the Fifth and Seventh are the most conservative. We also find striking similarities across circuits. In all circuits, Democratic appointees are more likely than Republican appointees to vote in a stereotypically liberal direction, and both party and panel effects are present. But in every circuit, in terms of likely vote, a judge's party makes no more difference than whether a judge is accompanied by two Democratic appointees or two Republican appointees.

Our main goal in this essay is simply to present and to analyze the data - to show the extent to which the three hypotheses find vindication. ${ }^{6}$ But we also aim to give some explanation for our findings and to relate them to some continuing debates about the role of ideology on federal panels. Our data do not reveal whether ideological dampening is a product of persuasion or a form of collegiality. If Republican appointees show a liberal pattern of votes when accompanied by two Democratic appointees, it might be because they are convinced by their colleagues. Alternatively, they might suppress their private

\footnotetext{
${ }^{6}$ Some of the findings here are previewed, without statistical analysis, in Cass R. Sunstein, Why Societies Need Dissent (2003).
} 
doubts and accept the majority's view. In any case, it is reasonable to say that the data show the pervasiveness of the collegial concurrence: a concurrence by a judge who signs the panel's opinion either because he is persuaded by the shared opinion of the two other judges on the panel or because it is not worthwhile, all things considered, to dissent. The collegial concurrence can be taken as an example, in the unlikely setting of judicial panels, of responsiveness to conformity pressures. ${ }^{7}$ These pressures make it more likely that people will end up silencing themselves, or even publicly agreeing with a majority position, simply because they would otherwise be isolated in their disagreement.

We also find evidence within the federal judiciary of group polarization, by which like-minded people end up in a more extreme position in accordance with their predeliberation views. ${ }^{8}$ If all-Republican panels are overwhelmingly likely to strike down campaign finance regulation, and if all-Democratic panels are overwhelmingly likely to uphold affirmative action programs, group polarization is likely to be a reason. Finally, we offer indirect evidence of a whistleblower effect: A single judge from another party, while likely to be affected by the fact that he is isolated, might also influence other judges on the panel, at least where the panel would otherwise fail to follow existing law. ${ }^{9}$

We believe that our findings are of considerable interest in themselves. They also reveal much about human behavior in many contexts. A great deal of social science evidence shows conformity effects: When people are confronted with the views of unanimous others, they tend to yield. ${ }^{10}$ Sometimes they yield because they believe that unanimous others cannot be wrong; sometimes they yield because it is not worthwhile to dissent in public. ${ }^{11} \mathrm{~A}$ great deal of social science evidence also shows that like-minded people tend to go to extremes. ${ }^{12}$ In the real world, this hypothesis is extremely hard to test in light of the range of confounding variables. But our data provide strong evidence that judges who are like-minded also go to extremes, in the sense that the probability that a judge will vote in one or another direction is increased by the presence of judges appointed by the president of the same political party. In short, we claim to show both strong conformity effects and group polarization within federal courts of appeals. If these effects can be shown there, then they are likely to be found in many diverse contexts.

In fact, the presence of such effects raises doubts about what is probably the most influential method for explaining judicial voting: the "attitudinal model."13 According to the attitudinal model, judges have certain "attitudes" toward areas of the law, and these

\footnotetext{
${ }^{7}$ See the overview in Solomon Asch, Opinions and Social Pressure, in Readings About the Social Animal 13 (Elliott Aronson ed. 1995).

${ }^{8}$ See David Schkade, Cass R. Sunstein, and Daniel Kahneman, Deliberating About Dollars, 100 Colum. L. Rev. 1139 (2001); Roger Brown, Social Psychology: The Second Edition (1985); Cass R. Sunstein, Why Societies Need Dissent (2003).

${ }^{9}$ See Frank Cross and Emerson Tiller, Judicial Partisanship and Obedience to Legal Doctrine, 107 Yale L.J. 2155 (1998).

${ }^{10}$ See id.

${ }^{11}$ See Robert Baron et al., Group Process, Group Decision, Group Action 66 (1999).

${ }^{12}$ Roger Brown, Social Psychology: The Second Edition 203-226 (1985).

${ }^{13}$ See Jeffrey Segal and James Spaeth, The Supreme Court and the Attitudinal Model Revisited (2002).
} 
attitudes are good predictors of judicial votes in difficult cases. ${ }^{14}$ Insofar as party effects are present, our findings are broadly supportive of this idea. But the attitudinal model does not come to terms with panel effects, which can both dampen and amplify the tendencies to which judicial "attitudes" give rise. Since panel effects are generally as large as party effects, and sometimes even larger, the attitudinal model misses a crucial factor behind judicial votes.

A disclaimer: We have collected a great deal of data, but our subtitle - a preliminary investigation - should be taken very seriously. The federal reporters offer an astonishingly large data set about judicial votes, including over two hundred years of votes ranging over countless substantive areas. Our own investigation is limited to several areas that, by general agreement, are ideologically contested, so much so as to produce possible disagreements in the cases that find their way to the courts of appeals. ${ }^{15}$ Of course it would be extremely interesting to know much more. ${ }^{16}$ Might ideological voting and panel effects be found in apparently nonideological cases, involving, for example, bankruptcy, torts, and civil procedure? What about the important areas of antitrust and labor law? How do the three hypotheses fare in the early part of the twentieth century, when federal courts were confronting the regulatory state? In cases involving minimum wage and maximum hour laws, did Republican appointees differ from Democratic appointees, and were panel effects also significant? Do the hypotheses hold in the segregation cases of the 1960s and 1970s? In the fullness of time, it should be possible to use the techniques discussed here to test a wide range of hypothesis about judicial voting patterns. One of our central goals is to provide a method for future analysis, a method that can be used in countless contexts.

\footnotetext{
${ }^{14}$ See id. We oversimplify a complex account.

${ }^{15}$ Note that the disciplining effect of existing law will be most constraining in disputes that never find their way to litigation; in such cases, everyone agrees what the law is, and it is not worthwhile to test that question. In disputes that are not litigated, it is safe to say that Republican appointees and Democratic appointees would agree almost all of the time. The doctrine should be expected to impose less discipline in cases that go to trial but that are not appealed; the decision to appeal suggests a degree of indeterminacy. Hence we are considering cases that are not only contested ideologically, but that also involve a sufficient lack of clarity in the law as to make it worthwhile to challenge a lower court ruling. Of course the highest degree of indeterminacy can be found in cases that are litigated to the Supreme Court. In the areas in which we find no effects from ideology - criminal appeals, takings, and federalism - such effects may nonetheless be found at the Supreme Court level.

${ }^{16}$ There is a sparse literature on panel effects. See Donald Songer, Consensual and Nonconsensual Decisions in Unanimous Opinions of the United States Courts of Appeals, 26 Amer. J. of Pol. Sci. 225-239 (1982); Burton Atkins and Justin Green, Consensus on the United States Courts of Appeals: Illusion or Reality? 20 Amer. J. of Pol. Sci.735-748 (1976); Burton Atkins, Judicial Behavior and Tendencies in a Three Member Small Group: A Case Study of Dissent Behavior on the U.S. Court of Appeals, 54 Social Science Quarterly 41 (1973); Sheldon Goldman, Conflict and Consensus in the United States Courts of Appeals, 1968 Wisconsin Law Review 461-482. We have found especially valuable Cross and Tiller, supra, and Richard L. Revesz, Environmental Regulation, Ideology, and the D.C. Circuit, 83 Va. L. Rev. 1717 (1997). On partisan voting, see id.; see also Donald Songer et al., Continuity and Change on the United States Courts of Appeals (2000); Davin Klein, Making Law in the United States Courts of Appeals (2002). A helpful overview of party effects is Daniel R. Pinello, Linking Party to Judicial Ideology in American Courts: A Meta-analysis, 20 Justice System J. 219 (1999).
} 
This essay is organized as follows. Part II offers the basic data, testing the three hypotheses in a number of areas. Part III disaggregates the data by exploring circuit results. Part IV speculates about the reasons for the various findings, with special attention to collegial concurrences, group polarization, and whistleblower effects. Part V investigates some normative issues.

\section{The Three Hypotheses}

\section{A. Aggregate Data}

We examined a total of 4,488 published panel decisions, and the 13,464 associated individual judge's votes, in the areas of abortion, ${ }^{17}$ capital punishment, ${ }^{18}$ Americans with Disabilities Act, ${ }^{19}$ criminal appeals, ${ }^{20}$ takings, ${ }^{21}$ contracts clause, ${ }^{22}$ affirmative action, ${ }^{23}$ Title VII race discrimination cases brought by African-American

\footnotetext{
${ }^{17}$ We assembled this sample of abortion cases by searching Lexis for "core-terms (abortion) and date aft 1982 and constitutional" and "abortion and constitution!". These cases generally presented challenges to statutes and policies that would infringe on a woman's right to choose, or challenges to the constitutionality of anti-protesting injunctions. Because plaintiffs differed between the cases, outcomes were coded as prolife or pro-choice; if a judge voted at all to support the pro-life position then it was counted as a pro-life vote. The sample includes cases from 01/01/82 - 12/31/02. We identified a total of 101 cases.

${ }^{18}$ We assembled this sample of capital punishment cases by searching Lexis for "capital punishment." If a judge voted to grant the defendant any relief, then the vote was coded as a pro-defendant vote. The sample includes cases from $01 / 01 / 95-12 / 31 / 02$. We identified a total of 181 cases.

${ }^{19}$ We assembled this sample of disability cases by searching Lexis for "Americans with Disabilities Act." If a judge voted to grant the plaintiff any relief, then the vote was coded as a pro-plaintiff vote. The sample includes cases from $01 / 01 / 98-12 / 31 / 02$. We identified a total of 682 cases.

${ }^{20}$ We assembled this sample of criminal cases from the D.C. Circuit, the Third Circuit, and the Fourth Circuit by searching http://www.ll.georgetown.edu/federal/judicial/cadc.cfm, http://vls.law.vill.edu/Locator/3/, and http://www.law.emory.edu/4circuit/2nd-idx.html, for cases with "United States" in title. Government appeals and civil disputes were disregarded. If a judge voted to grant the defendant any relief, then the vote was coded as a pro-defendant vote. The sample includes cases from $01 / 01 / 95-12 / 31 / 02$. We identified a total of 1176 cases.

${ }^{21}$ We assembled this sample of takings cases by shepardizing on Lexis Penn Central Transportation Co. v. New York City, 438 U.S. 104 (1978); Keystone Bituminous Coal Assn. v. DeBenedictis, 480 U.S. 470 (1987); Nollan v. California Coastal Commission, 483 U.S. 825 (1987); and Lucas v. South Carolina Coastal Council, 505 U.S. 1003 (1992). If a judge voted to grant the party alleging a violation of the takings clause any relief, then the vote was coded as a pro-plaintiff vote. The sample includes cases from 06/26/78 $-12 / 31 / 02$. We identified a total of 215 cases.

${ }^{22}$ We assembled this sample of contracts clause cases by shepardizing on Lexis Allied Structural Steel Co. v. Spannaus, 438 U.S. 234 (1978), and U.S. Trust Co. of New York v. New Jersey, 431 U.S. 1 (1977). If a judge voted to grant the party alleging a violation of the contracts clause any relief, then the vote was coded as a pro-plaintiff vote. The sample includes cases from 04/27/77 - 12/31/02. We identified a total of 76 cases.

${ }^{23}$ We assembled this sample of affirmative action cases by searching Lexis for "affirmative action and constitution or constitutional." The sample also includes cases found through a Westlaw Key Cite of United Steelworkers v. Weber, 443 U.S. 193 (1979) and Regents of the Univ. of California v. Bakke, 438 U.S. 265 (1978). If a judge voted any part of an affirmative action plan unconstitutional, then the vote was considered a vote for the party challenging the plan. The sample includes cases from 06/28/78 - 12/31/02. We identified a total of 155 cases.
} 
plaintiffs, ${ }^{24}$ sex discrimination, ${ }^{25}$ campaign finance, ${ }^{26}$ sexual harassment, ${ }^{27}$ cases in which plaintiffs sought to pierce the corporate veil, ${ }^{28}$ industry challenges to environmental regulations, ${ }^{29}$ and federalism challenges to congressional enactments under the commerce clause. ${ }^{30}$ Our methods for finding and assessing these cases, described in the footnotes, leave room for errors and for a degree of discretion. However, we are confident that the basic pattern of our results is sound. To keep the inquiry manageable, our investigation is limited to recent time periods (sometimes from 1995 to the present, though sometimes longer, certainly when necessary to produce a sufficient number of cases in a particular category $^{31}$ ). We believe that limited though the evidence is, our results are sufficient to show the range of likely patterns, and also to establish the claim that the three principal hypotheses are often vindicated.

Our sample is limited to published opinions. This limitation obviously simplifies research, but it also follows from our basic goal, which is to test the role of ideology in difficult cases rather than easy ones. As a general rule, unpublished opinions are widely agreed to be simple and straightforward, and to involve no difficult or complex issues of law. To be sure, publication practices are not uniform across circuits, and hence the decision to focus on published cases complicates cross-circuit comparisons. But that decision enables us to test our hypotheses in the cases that most interest us (and the

\footnotetext{
${ }^{24}$ We assembled this sample of Title VII cases by searching Lexis for "Title VII and African-American or black." We included cases that presented a challenge by an African-American plaintiff. If a judge voted to grant the plaintiff any relief, then the vote was coded as a pro-plaintiff vote. The sample includes cases from $01 / 01 / 85-12 / 31 / 02$. We identified a total of 320 cases.

${ }^{25}$ We assembled this sample of sex discrimination cases by searching Lexis for "sex! discrimination or sex! harassment." If the plaintiff was afforded any relief, then the vote was coded as a pro-plaintiff vote. The sample includes cases from 01/01/95 - 12/31/02. We identified a total of 1007 cases.

${ }^{26} \mathrm{We}$ assembled this sample of campaign finance cases by shepardizing on Lexis Buckley v. Valeo, 424 U.S. 1 (1976). If the party challenging the campaign finance provision was afforded any relief, then the vote was coded as a pro-plaintiff vote. The sample includes cases from 01/30/76-12/31/02. We identified a total of 55 cases.

${ }^{27}$ We assembled this sample of sexual harassment cases by searching Lexis for "sex! harassment." If the plaintiff was afforded any relief, then the vote was coded as a pro-plaintiff vote. The sample includes cases from $01 / 01 / 95-12 / 31 / 02$. We identified a total of 470 cases.

${ }^{28} \mathrm{We}$ assembled this sample of piercing the corporate veil cases by searching Lexis for "pierc! and corporate veil." If a judge afforded the plaintiff trying to pierce the veil any relief, then the vote was coded as a pro-plaintiff vote. The sample includes cases from 01/01/95 - 12/31/02. We identified a total of 106 cases.

${ }^{29}$ We assembled this sample of EPA cases by searching http://www.ll.georgetown.edu/federal/judicial/cadc.cfm for cases with "EPA" or the EPA Administrator's name in the case title. We crosschecked this set of cases with results from a Lexis search of "EPA" and "Environmental Protection Agency." If a judge voted to afford the industry challenger any relief, then the vote was coded as a pro-industry vote. The sample includes cases from 09/19/94-12/31/02. For cases before 1994, we relied on Richard L. Revesz, Environmental Regulation, Ideology, and the D.C. Circuit, 83 Va. L. Rev. 1717 (1997). We identified a total of 142 cases.

${ }^{30} \mathrm{We}$ assembled this sample of commerce clause cases by shepardizing on Lexis U.S. v. Lopez, 514 U.S. 549 (1995). If the plaintiff was afforded any relief, then the vote was coded as a pro-plaintiff vote. The sample includes cases from 4/26/95 - 12/31/02. We identified a total of 272 cases.

${ }^{31}$ Thus we extended the view screen to earlier cases when the post-1995 sample was small. In deciding how far to look, we typically relied on starting dates marked by important Supreme Court decisions that would predictably be cited in relevant cases.
} 
public), while also producing at least considerable information about the role of party and panel effects across circuits.

\footnotetext{
${ }^{32}$ Because unpublished opinions involve easy cases, we would not expect to see significant party or panel effects there, and a full sample of court of appeals opinions, including unpublished ones, would of course show reduced effects of both party and ideology. We emphasize that our goal is to see explore those effects in hard cases, not easy ones, and hence their absence from easy cases is essentially uninteresting.
} 


\section{Table 1. Summary of Votes by Individual Judges and Majority Decisions of Three-Judge Panels}

(proportion voting for the liberal position on the given issue)

\begin{tabular}{|c|c|c|c|c|c|c|c|c|c|c|c|c|}
\hline \multirow[b]{3}{*}{ Case Type } & \multicolumn{7}{|c|}{ Individual Judges' Votes } & \multicolumn{5}{|c|}{ Panel Majority Decisions } \\
\hline & \multicolumn{3}{|c|}{ Party } & \multicolumn{4}{|c|}{ Panel Colleagues } & \multicolumn{5}{|c|}{ Panel Composition } \\
\hline & $\mathrm{R}$ & $\mathrm{D}$ & $\mathbf{D}-\mathbf{R}$ & $\mathrm{RR}$ & $\mathrm{RD}$ & DD & $\begin{array}{c}\text { DD - } \\
\text { RR }\end{array}$ & RRR & RRD & RDD & DDD & $\begin{array}{c}\text { DDD - } \\
\text { RRR }\end{array}$ \\
\hline Campaign finance (vote to uphold) & .28 & .46 & .18 & .29 & .34 & .53 & .24 & .23 & .30 & .35 & .80 & .57 \\
\hline Affirmative action (vote for) & .48 & .74 & .26 & .47 & .62 & .73 & .26 & .37 & .50 & .83 & .85 & .48 \\
\hline EPA (vote against industry) & .46 & .64 & .18 & .48 & .54 & .66 & .19 & .27 & .55 & .62 & .72 & .45 \\
\hline Sex discrimination (vote for Plaintiff) & .35 & .51 & .16 & .36 & .41 & .57 & .21 & .31 & .38 & .49 & .75 & .44 \\
\hline Contracts (reject const challenge) & .24 & .30 & .06 & .19 & .26 & .45 & .26 & .16 & .26 & .32 & .50 & .34 \\
\hline Pierce corp veil (vote to pierce) & .27 & .41 & .14 & .25 & .31 & .51 & .26 & .23 & .29 & .37 & .56 & .33 \\
\hline ADA (vote for Plaintiff) & .26 & .43 & .17 & .24 & .35 & .45 & .21 & .18 & .27 & .47 & .50 & .32 \\
\hline Abortion (vote pro-choice) & .49 & .70 & .21 & .58 & .55 & .65 & .07 & .53 & .51 & .62 & .78 & .25 \\
\hline Capital punishment (vote against) & .20 & .42 & .22 & .29 & .29 & .30 & .01 & .18 & .22 & .38 & .33 & .15 \\
\hline Title VII cases (vote for Plaintiff) & .35 & .41 & .06 & .39 & .35 & .42 & .04 & .43 & .31 & .45 & .56 & .13 \\
\hline Federalism (vote to uphold) & .95 & .99 & .04 & .96 & .97 & .97 & .01 & .97 & 1.00 & .98 & 1.00 & .03 \\
\hline Criminal (vote for Defendant) & .33 & .36 & .03 & .33 & .33 & .33 & .00 & .31 & .31 & .40 & .34 & .02 \\
\hline Takings clause (find no taking) & .23 & .20 & -.03 & .23 & .20 & .23 & .00 & .26 & .17 & .24 & .25 & -.01 \\
\hline Average across all case types & .38 & .51 & .13 & .39 & .43 & .52 & .14 & .34 & .39 & .50 & .61 & .27 \\
\hline Case types with a panel difference & .34 & .50 & .16 & .35 & .40 & .53 & .17 & .29 & .36 & .49 & .64 & .35 \\
\hline
\end{tabular}

Table 1 shows the percentage of stereotypically liberal votes ${ }^{33}$ in a variety of areas, for individual votes, and for the majority decisions of three-judge panels. Note first that in a number of areas, there is strong evidence of ideological voting, in the sense that Democratic appointees are more likely to vote in the stereotypically liberal direction than are Republican appointees. We measure ideological voting by subtracting the percentage of liberal Republican votes from the percentage of liberal Democratic votes; the larger the number, the larger the party effect. The overall difference is $13 \%$ - not huge, but substantial. The extent of this effect, and even its existence, is variable across areas. We shall discuss these variations shortly.

We can also see that the votes of judges are influenced by the party affiliation of the other two judges on the same panel. We measure this influence by subtracting the overall percentage of liberal votes by a judge when sitting with two Democratic appointees from the percentage when they sit with two Republican appointees. Surprisingly, this overall difference, $14 \%$, is as large as the basic difference between parties.

\footnotetext{
${ }^{33}$ For simplicity of analysis and clarity of presentation we coded votes for all case types in the same ideological direction. Identical results would come using conservative votes, but with the sign reversed.
} 


\section{Figure 1. Party and Panel Influences on Votes of Individual Judges}

(on average for ideological case types)

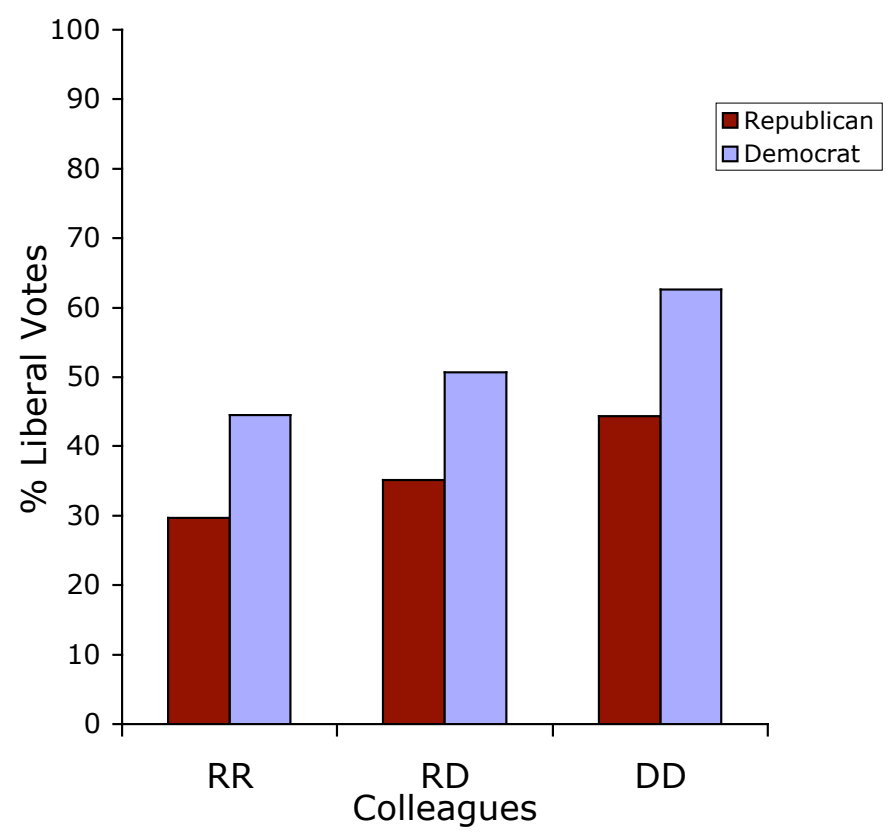

Finally, it is clear that these two influences result in actual decisions that are very much affected by the composition of the panel. The clearest point is a sharp spread between the average outcome in an all-Republican panel and that in all-Democratic panel. Indeed, the likelihood of a liberal outcome is twice as high with the latter as with the former. For litigants in highly controversial areas, a great deal depends on the luck of the draw - the outcome of a random assignment of judges.

Figure 1 captures the aggregate party and panel effects across those areas in which there is ideological voting. ${ }^{34}$ The most striking lessons of this figure are our principal themes here. ${ }^{35}$ For both Democratic appointees and Republican appointees, the likelihood of a liberal vote jumps when the two other panel members are Democratic

\footnotetext{
${ }^{34} \mathrm{We}$ exempt cases in which there is little or no ideological voting (criminal cases, takings cases, and federalism cases). If those cases were included, then we would see the same overall patterns, but in diminished form. If we exempted cases of ideological voting without panel effects (abortion, capital punishment), the aggregate panel effects would of course be more pronounced.

${ }^{35}$ The data were analyzed using a logistic regression model with the vote (liberal/conservative) of an individual judge on a given case as the dependent variable. The independent variables were the judge's Party (Democrat/Republican appointee), the number of Democrat appointees among the other two judges on the Panel, and dummy variables for Case Category and Circuit. Results for this overall model appear in the Appendix. For analyses of individual case categories, the model is the same but with case category dummies dropped; for analyses of circuits the circuit dummies are dropped. In the aggregate analysis of Figure 1 the coefficients for Party $(\mathrm{p}<.001)$ and Panel $(\mathrm{p}<.001)$ are both highly significant. There is also a slight tendency for Democratic appointees to show larger panel effects that Republican appointees (the interaction term is marginally significant, $\mathrm{p}<.07$ ).
} 
appointees, and it drops when the two other panel members are Republican appointees. For purposes of discussion, we might take, as the baseline, cases in which a judge is sitting with one Democrat and one Republican, and compare how voting patterns shift when a judge is sitting instead with two Democratic appointees or two Republican appointees. We can readily see that a Democrat, in the baseline condition, casts a liberal vote $60 \%$ of the time, whereas a Republican does so $46 \%$ of the time. Sitting with two Democratic appointees, Democratic appointees cast liberal votes $66 \%$ of the time, whereas Republican appointees do so $54 \%$ of the time. Sitting with two Republican appointees, Democratic appointees cast liberal votes $53 \%$ of the time, whereas Republican appointees do so only $34 \%$ of the time. Thus Republican appointees, sitting with two Democratic appointees, show the same basic pattern of votes as do Democratic appointees, sitting with two Republican appointees.

But the aggregate figures conceal some significant differences across case categories. We begin with cases in which all three hypotheses are supported, and then turn to cases in which they are not.

\section{B. All Hypotheses Supported}

Affirmative action. Let us start with affirmative action, which shows the basic pattern of results as in the aggregate data (Figure 2). ${ }^{36}$ From 1980 through 2002 , Republican appointees cast 267 total votes, with 127, or 48\%, in favor of upholding an affirmative action policy. By contrast, Democratic appointees cast 198 votes, with 147, or $74 \%$, in favor of upholding an affirmative action policy. Here we find striking evidence of ideological voting. But we also find significant evidence of panel effects. An isolated Democrat, sitting with two Republican appointees, votes for affirmative action only $61 \%$ of the time - halfway between the aggregate numbers for Democratic appointees and Republican appointees. More remarkably, isolated Democratic appointees are actually slightly less likely to vote for affirmative action programs than are isolated Republican appointees, who vote in favor $65 \%$ of the time. Thus we see strong evidence of ideological dampening.

The third hypothesis is also confirmed. On all-Republican panels, individual Republican appointees vote for affirmative action programs $37 \%$ of the time, as compared with 49\% when Republican appointees hold a two-to-one majority. On allDemocratic panels, individual Democratic appointees vote in favor of the plan $82 \%$ of the time, compared to $80 \%$ with a two-judge Democratic majority. An institution defending an affirmative action program has about a one-in-three chance of success before an allRepublican panel - but more than a four-in-five chance before an all-Democratic panel! In a pattern that captures many of the doctrinal areas, the rate of pro-affirmative action votes on all-Democratic panels is almost triple the corresponding rate of Republican votes on all-Republican panels.

\footnotetext{
${ }^{36}$ The coefficients for Party $(\mathrm{p}<.001)$ and Panel $(\mathrm{p}<.001)$ are both significant.
} 
Figure 2. Voting Patterns for Case Types with Both Party and Colleague Effects

$(\square($ red $)=$ Republican appointees, $\mathbf{( b l u e})=$ Democratic appointees)
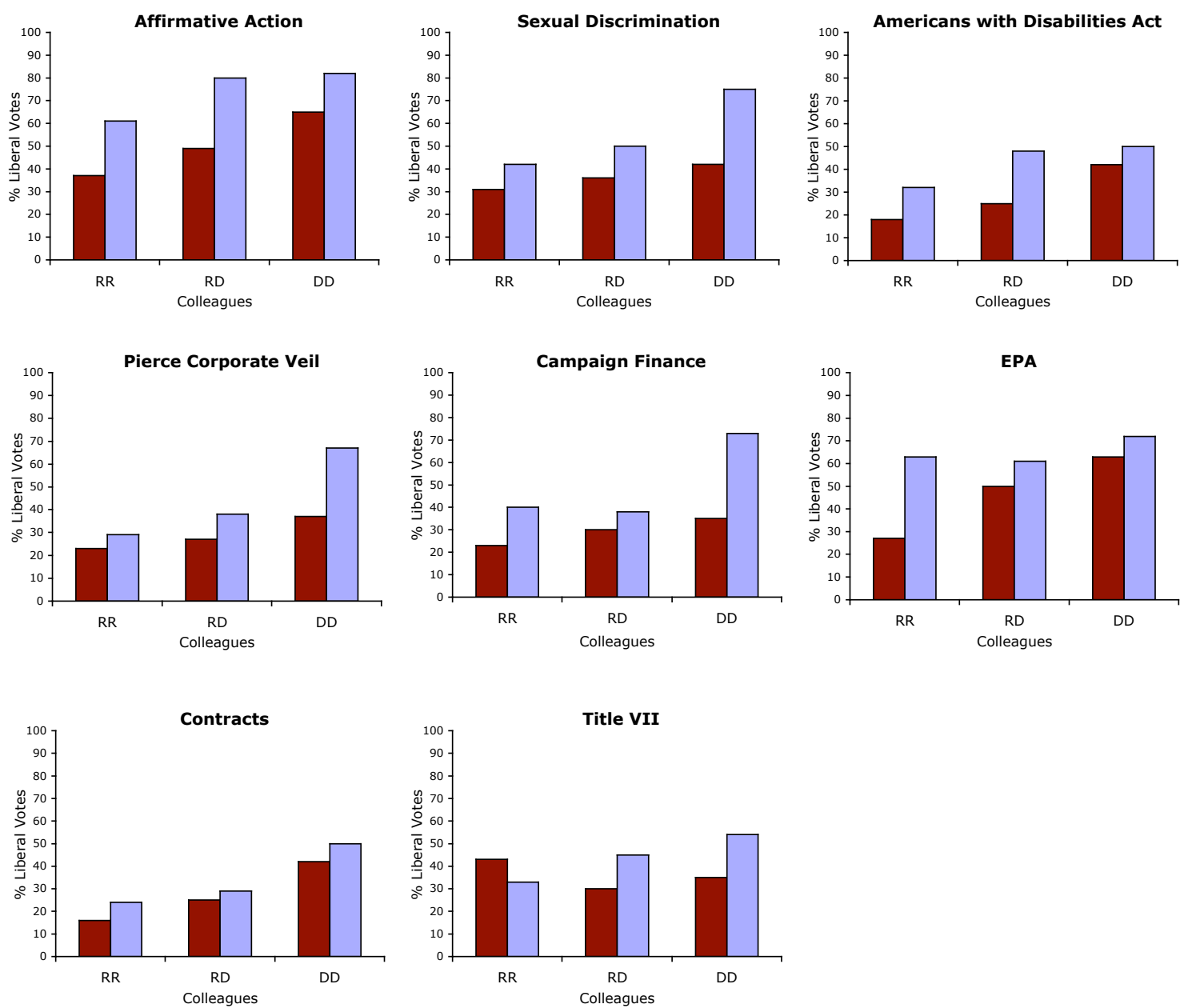

Sex discrimination. In sex discrimination cases from 1995 to the present, Republican appointees voted in favor of plaintiffs 35\% to the time, whereas Democratic appointees voted for plaintiffs $51 \%$ of the time. Hence we find strong ideological voting, though not as strong as in the affirmative action context. ${ }^{37}$ When in the minority, Republican appointees vote in favor of sex discrimination plaintiffs $42 \%$ of the time, identical to the $42 \%$ rate of Democratic appointees when they are in the minority. The most striking number here is the percentage of pro-plaintiff votes when Democratic appointees are sitting together. Here $75 \%$ of Democratic votes favor plaintiffs, far higher than the rates of $50 \%$ or less when Democratic appointees sit with one or more Republican appointees. On all-Republican panels, Republican appointees vote at a strongly anti-plaintiff rate, with only $31 \%$ favoring plaintiffs, although this rate increases steadily with each Democrat on a panel.

${ }^{37}$ The coefficients for Party $(\mathrm{p}<.001)$ and Panel $(\mathrm{p}<.001)$ are both significant. 
Sexual harassment. Sexual harassment cases are a subset of sex discrimination cases; for that reason, they have not been included as a separate entry in our aggregate figures. But because the area is of considerable independent interest, we have conducted a separate analysis of sexual harassment cases. ${ }^{38}$ Republican appointees vote in favor of plaintiffs at a rate of $37 \%$, whereas Democratic appointees vote for plaintiffs at a rate of $52 \%$. Sitting with two Democratic appointees, Republican appointees are more likely to vote for plaintiffs than Democratic appointees sitting with two Republican appointees, by a margin of $44 \%$ to $41 \%$. On all-Democratic panels, Democratic appointees vote for plaintiffs at a $76 \%$ rate, more than double the $32 \%$ rate of Republican appointees on allRepublican panels. It might be expected that gender would be relevant to rulings in sexual harassment cases, and for this reason we did a separate analysis of whether gender predicts likely votes. The answer is that gender does not matter. Female judges are not more likely than male judges to vote in favor of plaintiffs in these cases, and judges who sit with one or more female judge are not more likely to vote for plaintiffs than those who sit only with male judges. The party of the appointing president, not gender, is the important variable here.

Disability. Under the Americans with Disabilities Act, judges of both parties are influenced by the colleagues with whom they sit on a panel..$^{39}$ In data collected for the period from 1998 to $2002,{ }^{40}$ Republican appointees vote $26 \%$ of the time in favor of plaintiffs; sitting with one Republican and one Democrat, the rate is $25 \%$, about the same as the aggregate figure. But when sitting with two Republican appointees, the rate drops to $18 \%$, and when sitting with two Democratic appointees, it jumps to $42 \%$. Democratic percentages move in the same directions, though with a slightly different pattern. The overall pro-plaintiff vote is $43 \%$, but it is $32 \%$ when a Democratic appointee sits with two Republican appointees (significantly lower than the $42 \%$ rate for Republican appointees sitting with two Democratic appointees), and it rises to $48 \%$ with one other Democrat and to $50 \%$ on all-Democratic panels.

Piercing the corporate veil. Cases in which plaintiffs attempt to pierce the corporate veil follow a very similar pattern to that for sexual discrimination, with all three hypotheses confirmed. ${ }^{41}$ Republican appointees accept such claims at a significantly lower rate than Democratic appointees: $27 \%$ as opposed to $41 \%$. But here as elsewhere, a Republican, sitting with two Democratic appointees (37\% in favor of veil-piercing), is more liberal than a Democrat, sitting with two Republican appointees (29\%). The most extreme figures in the data involve unified panels. Here too the pro-plaintiff voting percentage of Democratic appointees, on all Democratic-panels, is almost triple the corresponding number for Republican appointees, on all-Republican panels: $67 \%$ as opposed to $23 \%$.

\footnotetext{
38 The coefficients for Party $(\mathrm{p}<.001)$ and Panel $(\mathrm{p}<.001)$ are both significant.

39 The coefficients for Party $(\mathrm{p}<.001)$ and Panel $(\mathrm{p}<.001)$ are both significant.

${ }^{40}$ The sample is very large here, so we thought it unnecessary to collect earlier data to test our three hypotheses.

${ }^{41}$ The coefficients for Party $(\mathrm{p}<.01)$ and Panel $(\mathrm{p}<.001)$ are both significant.
} 
Campaign finance. In cases since 1976, Republican appointees cast only $28 \%$ of their votes in favor of upholding campaign finance laws, substantially lower than the $46 \%$ rate for Democratic appointees. Hence the first hypothesis - ideological voting - is tentatively supported. ${ }^{42} \mathrm{With}$ respect to the second hypothesis, involving ideological dampening, the results are suggestive as well. When sitting with two Democratic appointees, Republican appointees voted to uphold campaign finance laws 35\% of the time. And when sitting with two Republican appointees, Democratic appointees voted for such programs $40 \%$ of the time.

Now turn to the third hypothesis, involving ideological amplification. On allRepublican panels, Republican appointees voted to uphold $23 \%$ of the time, while on allDemocratic panels, Democratic appointees voted to uphold $73 \%$ of the time. The corresponding numbers, on two-judge majority panels, are $30 \%$ and $38 \%$ respectively. Thus there is evidence of a substantial difference between the behavior of all-Democratic panels and Democratic majority panels; but the same is not true for Republican appointees.

Environmental regulation. A large data set, much of it compiled and explored by Dean Revesz, ${ }^{43}$ comes from industry challenges to EPA regulations. We have added a great deal to Revesz's data set here, ${ }^{44}$ though like Revesz, we limit our findings to the D.C. Circuit, which hears the vast majority of environmental cases. ${ }^{45}$ From 1970 through 2002, Democratic appointees voted against agency challenges $64 \%$ of the time, whereas Republican appointees did so $46 \%$ of the time. ${ }^{46}$ There are also significant findings of group influence. ${ }^{47}$ Republican appointees show ideological amplification. On allRepublican panels, Republican appointees vote against industry challenges just $27 \%$ of the time; but for members of two-Republican majorities this figure rises rapidly to $50 \%$, and finally to $63 \%$ for a single minority Republican.

Interestingly, Democratic appointees do not show ideological amplification in this domain. A single Democratic appointee, accompanied by two Republican appointees, votes against industry challenges $63 \%$ of the time; but when joined by two Democratic appointees, the rate rises only to $72 \%$. Their invalidation rates are largely impervious to panel effects. But as Dean Revesz has shown, ideological amplification can be found among Democratic appointees when an environmental group is challenging agency

\footnotetext{
${ }^{42}$ Here we are hampered by the small number of campaign finance cases available. The coefficient for Party almost achieves significance $(\mathrm{p}=.13)$ and the Panel coefficient is positive but not significantly different from zero $(\mathrm{p}=.35)$. We include campaign finance cases in this group of case categories because it has a matching pattern that would be highly significant, given a larger number of cases.

${ }^{43}$ See Richard L. Revesz, Environmental Regulation, Ideology, and the D.C. Circuit, 83 Va. L. Rev. 1717 (1997).

${ }^{44}$ See id.

${ }^{45}$ The coefficients for Party $(\mathrm{p}<.001)$ and Panel $(\mathrm{p}<.001)$ are both significant.

${ }^{46}$ Using a smaller data set than that used here, Revesz finds that when industry challenges an environmental regulation, there is an extraordinary difference between the behavior of a Republican majority and that of a Democratic majority. Republican majorities reverse agencies over $50 \%$ of the time; Democratic majorities do so less than $15 \%$ of the time. Richard L. Revesz, Ideology, Collegiality, and the D.C. Circuit, 85 Va. L. Rev. 805, 808 (1999).

${ }^{47}$ See id. at 808 (1999).
} 
action. A panel of three Democratic appointees is more likely to accept the challenge than a panel of two Democratic appointees and one Republican. ${ }^{48}$ The likelihood that a Democrat will vote in favor of an environmentalist challenge is highest when three Democratic appointees are on the panel - and lowest when the panel has two Republican appointees. $^{49}$

Contracts clause violations. We examined contracts clause cases with the thought that Republican appointees would be more sympathetic than Democratic appointees to contracts clause claims. Our speculation to this effect was rooted in the fact that conservative academics have argued for stronger judicial protection of contractual rights. ${ }^{50}$ But our speculation turned out to be wrong. There is mild evidence of ideological voting with respect to the contracts clause, but it runs in the opposite direction from what we predicted, apparently because those who make contracts clause objections are more sympathetic to Democratic than to Republican appointees. ${ }^{51}$

In cases from 1995 to the present, Republican appointees vote on behalf of plaintiffs $24 \%$ of the time, whereas Democratic appointees do so $30 \%$ of the time. More striking in this context are the panel effects, which are large for both parties. On allDemocratic panels, Democratic appointees vote in favor of plaintiffs $50 \%$ of the time; on all-Republican panels, Republican appointees vote in favor of plaintiffs only $16 \%$ of the time. But the dampening effects are large and in the predicted direction. Sitting with two Democratic appointees, Republican appointees vote in favor of plaintiffs in $42 \%$ of the cases, whereas a Democrat sitting with two Republican appointees does so just $24 \%$ of the time.

Title VII. In cases brought under Title VII by African-American plaintiffs, we find small but nearly statistically significant evidence of ideological voting: Democratic appointees vote for plaintiffs $41 \%$ of the time, whereas Republican appointees do so $35 \%$ of the time. ${ }^{52}$ Democratic appointees also show ideological dampening, with a $33 \%$ proplaintiff vote when sitting with two Republican appointees, and ideological amplification, with a 54\% pro-plaintiff vote when sitting with two Democratic appointees. The pattern for Republican appointees is a bit of a puzzle. When sitting with two Republican appointees, Republican appointees actually vote for plaintiffs at a higher rate $-43 \%-$ than when sitting with one or more Democratic appointees. When sitting with two Democratic appointees, Republican appointees vote for plaintiffs at a $35 \%$ rate, slightly higher than the $30 \%$ rate shown when sitting with one Democrat and one Republican. Overall, this is a similar pattern to others with both party and colleague effects, except for

\footnotetext{
${ }^{48}$ Id. at 1753 .

${ }^{49} \mathrm{Id}$.

${ }^{50}$ See Richard Epstein, Toward a Revitalization of the Contract Clause, 51 U. Chi. L. Rev. 703, 704-05 (1984).

51 The coefficient for Party is not significantly different from zero $(\mathrm{p}>.30)$ but the Panel coefficient is significant $(\mathrm{p}<.01)$. We include contracts clause cases here because of the panel effect.

${ }^{52}$ Neither the coefficient for Party $(\mathrm{p}=.18)$ nor that for Panel $(\mathrm{p}>.30)$ is significantly different from zero. We include Title VII cases here because expect for the anomalous pattern for all-Republican panels, the remainder of the pattern looks similar to the rest of this groups of case categories. Indeed, if we drop the RRR group, both Party and Panel effects are significant.
} 
the apparently anomalous voting of all-Republican panels, for which we have no good explanation.

\section{All Hypotheses Rebutted}

In three areas, all of our hypotheses were rebutted (Figure 3 ). The simple reason is that there is no significant difference between the votes of Republican appointees and those of Democratic appointees. Contrary to expectations, the political affiliation of the appointing President does not matter in the contexts of criminal appeals, federalism, and takings.

\section{Figure 3. Voting Patterns for Case Types with Neither Party nor Colleague Effects}

$(\square($ red $)=$ Republican appointees, $\square$ (blue) = Democratic appointees)
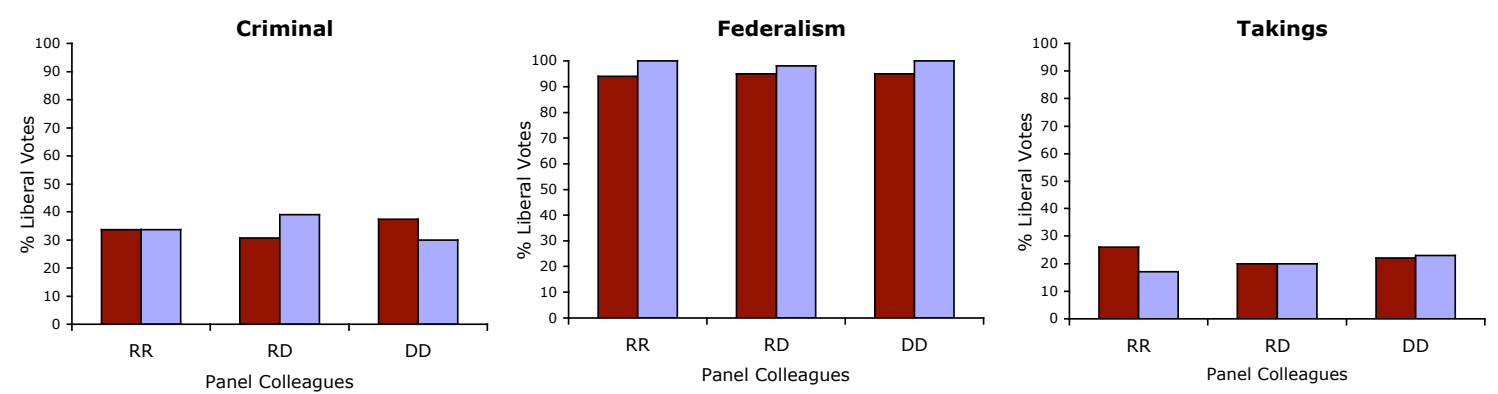

Criminal Appeals. It might be anticipated that Democratic appointees would be especially sympathetic to criminal defendants and that Republican appointees would be relatively unsympathetic. At least this is a popular platitude about judicial behavior. Hence the three hypotheses might be anticipated to receive strong support. But all of them are rejected, at least in three courts of appeals from 1995 to the present. ${ }^{53} \mathrm{We}$ selected the courts of appeals for the District of Columbia Circuit and for the Third and Fourth Circuits, on the theory that we would be highly likely to find ideological voting in criminal cases in these circuits. However, we found no such effects. The overall rate of votes for defendants is between $30 \%$ and $39 \%$, with no significant differences between Republican appointees and Democratic appointees, and without significant panel effects. We conclude that Republican appointees and Democratic appointees do not much differ in this domain; we attempt to explain this finding below.

Federalism and the commerce clause. Since 1995, the overwhelming majority of federal judicial votes have been in favor of the constitutionality of programs challenged under the commerce clause. Indeed, Democratic appointees vote to validate the challenged program over $99 \%$ of the time. The numbers are not materially different for

\footnotetext{
${ }^{53}$ Neither the coefficient for Party nor that for Panel is significantly different from zero.
} 
Republican appointees, for whom the overall validation rate is $95 \%$. No panel effects are observed. ${ }^{54}$ A possible reason for the agreement is that for many decades, the Supreme Court gave a clear signal that courts should be reluctant to invalidate congressional enactments under the commerce clause. ${ }^{55}$ To be sure, the Court has given recent signals about its willingness to invoke that clause against Congress. ${ }^{56}$ However, neither Republican nor Democratic appointees seem to believe that those signals should be taken very seriously. Perhaps things will change in this regard as the lower courts internalize the Court's messages.

Takings. When plaintiffs challenge a governmental decision as violative of property rights, Democratic appointees and Republican appointees again show no significant differences. ${ }^{57}$ Only $23 \%$ of Republican votes are in favor of such challenges. It might be expected that Democratic appointees would show a substantially lower level of invalidation rates, but the percentage of Democratic votes to invalidate is nearly identical: $20 \%$. No panel effects can be found.

\section{Ideological Voting Without Amplification or Dampening: The Unique Cases of Abortion and Capital Punishment}

It would be possible to imagine areas dominated by ideological voting. In such areas, judges would be expected to vote in a way that reflects the political affiliation of the appointing president - but panel effects would be minimal. This is the pattern of outcomes in only two areas that we investigated: abortion and capital punishment (Figure 4).

Figure 4. Voting Patterns for Case Types with Only a Party Effect

$(\square($ red $)=$ Republican appointees, $\square($ blue $)=$ Democratic appointees $)$
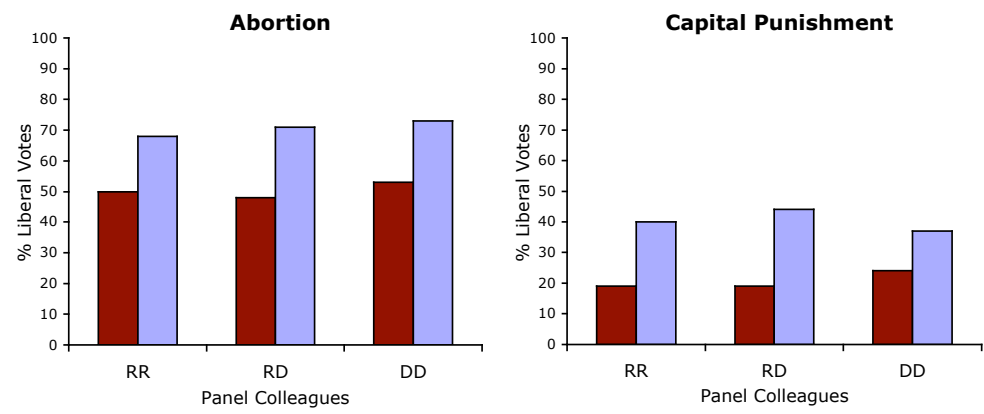

${ }^{54}$ Neither the coefficient for Party nor that for Panel is significantly different from zero.

55 See Geoffrey Stone et al., Constitutional Law ( $5^{\text {th }}$ ed. 2001).

${ }^{56}$ See United States v. Lopez; Morrison.

${ }^{57}$ Neither the coefficient for Party nor that for Panel is significantly different from zero. 
Democratic appointees cast pro-abortion votes $70 \%$ of the time, compared to $49 \%$ for Republican appointees. Here again we find evidence of ideological voting. But panel effects are absent. Sitting with two Democratic appointees, Republican appointees vote in favor of invalidation $53 \%$ of the time, not appreciably different from the $48 \%$ rate when sitting with one or more Republican appointees and the $50 \%$ invalidation rate in all Republican panels. Similarly, sitting with two Republican appointees, Democratic appointees vote in favor of abortion rights $68 \%$ of the time, not much less than the $71 \%$ and $73 \%$ rates when sitting with one or two other Democratic appointees, respectively. The failure of the third hypothesis is even more striking. A Republican vote, on an allRepublican panel, is essentially the same as on a panel of two Republican appointees and one Democrat; a Democratic vote, on an all-Democratic panel, is essentially the same as on a panel of two Democratic appointees and one Republican.

Capital punishment shows a similar pattern: a large party difference, but no other significant effects. Republican appointees vote for defendants $19 \%$ of the time on allRepublican panels; $19 \%$ of the time on majority Republican panels; and $24 \%$ of the time on majority Democratic panels. Democratic appointees vote for defendants $37 \%$ of the time on all-Democratic panels; $44 \%$ of the time on majority Democratic panels; and $40 \%$ of the time on majority Republican panels.

\section{E. Panel Decisions}

Thus far we have focused on the votes of individual judges. For litigants and the law, of course, it is not the votes of individual judges, but the decisions of three-judge panels, that are of real interest. Let us now turn to panel outcomes.

In terms of the political affiliation of the appointing president, there are four possible combinations of judges on a three-judge panel: RRR, RRD, RDD, and DDD. Variations in panel composition can have two important effects, which should now be distinguished. The first involves the sheer number of people leaning in a certain direction. Suppose, for example, that Republican appointees are likely to rule in favor of a particular type of program only $40 \%$ of the time, whereas Democratic appointees are likely to rule in favor of such programs $70 \%$ of the time. As a simple statistical matter, and putting to one side the possibility that judges are influenced by one another, it follows that the likely majority outcome of a panel will be affected by its composition, so that (for example) a panel of all-Democratic appointees is far more likely (78\%) to uphold an the program than a panel of two Democratic appointees and one Republican $(66 \%)$, while an all-Republican panel would be much less likely to do so $(35 \%) .{ }^{58}$

\footnotetext{
${ }^{58}$ These figures come from the multinomial probabilities of getting at least two votes to uphold (a Yes vote), given the panel composition. For a three-judge panel, there are four ways to get a decision to uphold - votes of YYY, YYN, YNY, and NYY, from judges 1, 2 and 3, respectively. For example, for an allDemocratic appointed panel (DDD), the probability of a vote to uphold the program is $\mathrm{P}(\mathrm{YYY})+\mathrm{P}(\mathrm{YYN})$ $+\mathrm{P}(\mathrm{YNY})+\mathrm{P}(\mathrm{NYY})=.7 * .7 * .7+.7 * .7 *(1-.7)+.7 *(1-.7) * .7+(1-.7) * .7 * .7=.343+.147+.147+.147=$ .784 , which rounds to $78 \%$; for one Republican and two Democrats (RDD), the calculation is . $4 * .7 * .7+$ $.4 * .7 *(1-.7)+.4 *(1-.7) * .7+(1-.4) * .7 * .7=.196+.084+.084+.294=.658$; and so forth.
} 
This is an important and substantial difference. But as noted, this statistical effect assumes that judicial votes are not influenced by judicial colleagues. Suppose that an individual judge's likely vote is in fact influenced by the composition of the panel. If so, then the mere majority force of predispositions, just described, will not tell the full story of the difference between all-Republican panels and all-Democratic panels. In fact the statistical account will understate the difference, possibly substantially. To illustrate with our own data, let us assume for the moment that the average percentages reported in the bottom row of Table 1 do accurately represent individual voting tendencies for case types that show differences in panel decisions. Figure 5 compares the predicted percentages, based on 34\% for Republican appointees and 51\% for Democratic appointees and using the calculation above, to the observed averages from the same row of the Table. The predicted panel effect (DDD\% - RRR\%) is $24 \%$, but the observed difference is $35 \%$. It is clear that to explain these results, something must be at work other than majority voting with different ideological predictions. ${ }^{59}$

\footnotetext{
${ }^{59}$ If the shape of the graph were to hold up, it would suggest that the largest disparities occur when Democratic appointees are in the majority. This conclusion is tentative, of course, because of the lack of a clean or simple measure of the "true" party difference.
} 
Figure 5. Predicted vs. Actual Panel Decisions

(for case types with a panel difference)

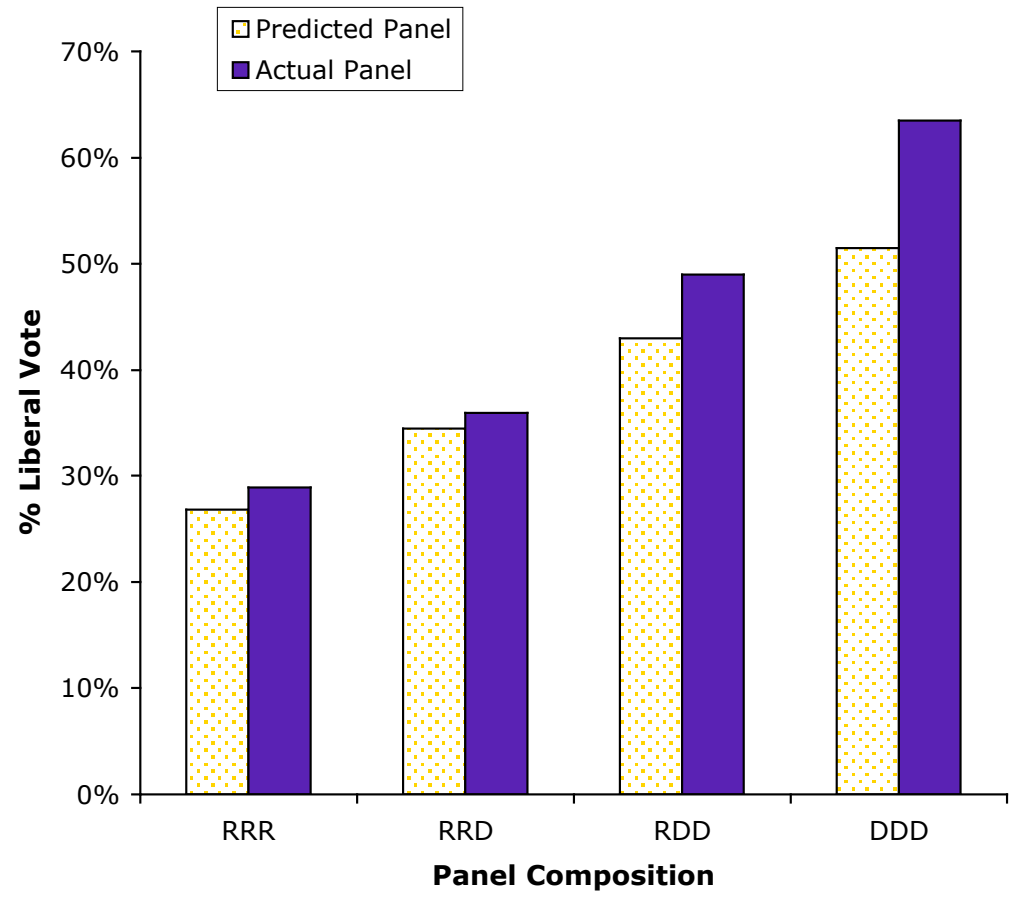

III. Disaggregating by Circuit

There are twelve federal courts of appeals, and it is therefore possible to disaggregate the cases by circuit, to see whether the effects observed in the aggregate data hold across the board. In some contexts, the sample is too small to allow for reliable generalizations. To obtain a sense of what is happening across circuits, we aggregated the various cases within circuits. ${ }^{60}$ The simplest finding has to do with ideological variations across circuits.

Consider Figure 6. In accordance with standard lore, the Ninth and Second Circuits are two of the most liberal, and the Fifth and Seventh Circuits are two of the most conservative. The rankings, in terms of ideology, correlate strongly (but not perfectly) with the percentage of Democratic appointees on the relevant court in 2002 ( $\mathrm{r}=$ $.59) .{ }^{61}$ Note that the figure, while suggestive, is a bit crude. In many contexts, litigants have some discretion about the circuit in which to bring suit, and hence civil rights

${ }^{60}$ To provide a common basis for comparing the circuits, we analyzed those case types with party differences, as in Figures 1-4, but also excluded environmental cases, which were only brought in the DC circuit.

${ }^{61}$ Of course, since our cases occurred over many years, an analysis that more carefully matched the year of the case with the then-current composition of the relevant circuit could show a stronger relationship. 
plaintiffs would prefer to sue in the Ninth Circuit rather than the Seventh. But broadly speaking, the figure probably captures ideological differences across circuits.

Figure 6. Circuit Composition and Individual Voting Patterns

(sorted by $\%$ of liberal votes)

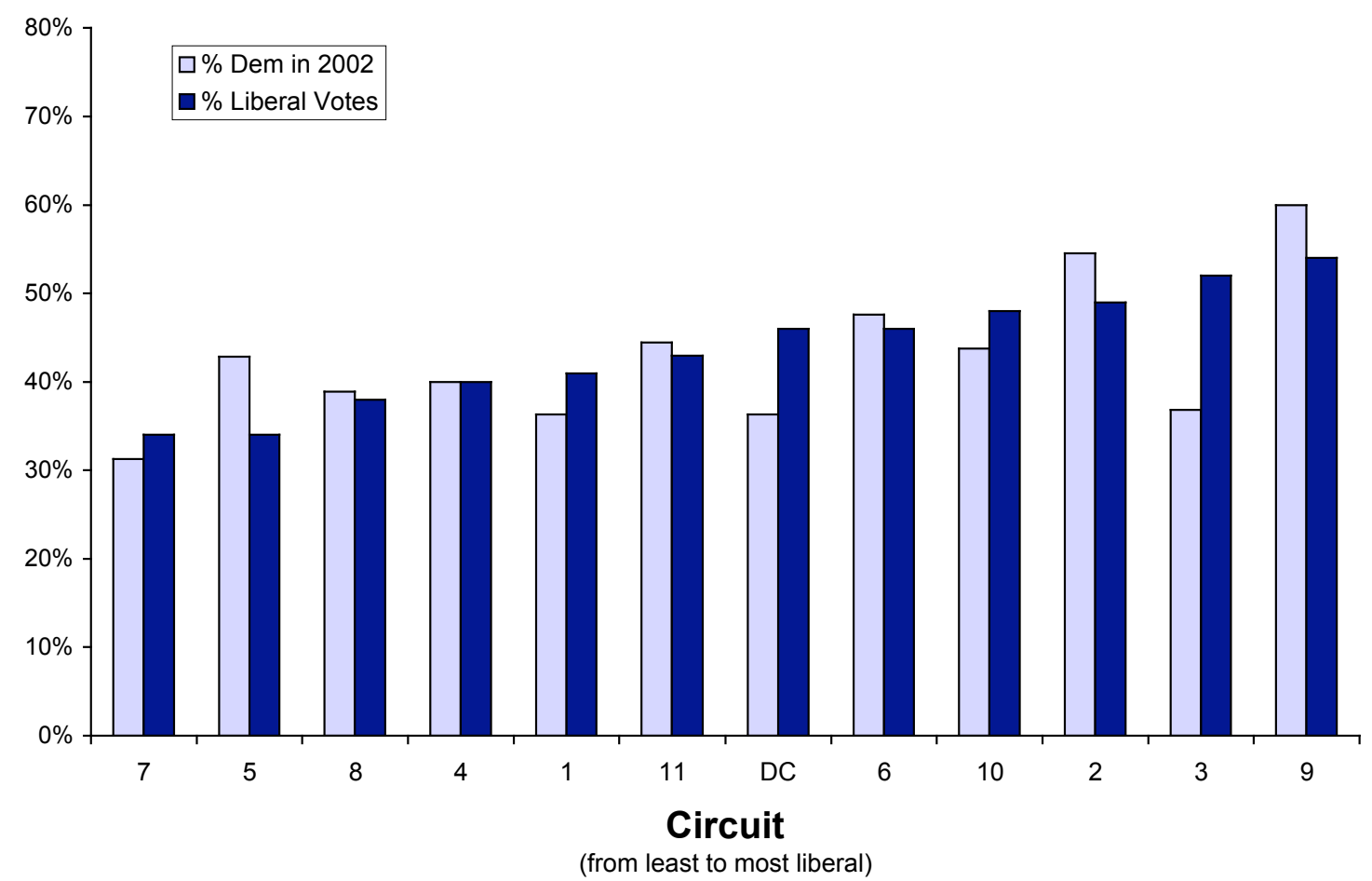

Now turn to another question: Whether the effects of party and panel differ across circuits. As before, to obtain a measure of party effects, we subtract the percentage of liberal votes by Republican appointees from the percentage of liberal votes by Democratic appointees; this is a good test for whether party predicts likely votes. Similarly, to create our measure of panel effects, we subtract the percentage of liberal votes by judges (whether Republican or Democrat) sitting with two Republican appointees from the percentage of such votes of judges sitting with two Democratic appointees. Figure 7 presents the results. There are party differences in all circuits, although they do differ in magnitude. The $3^{\text {rd }}, 5^{\text {th }}$ and $7^{\text {th }}$ circuits show small party differences (less than $8 \%$ ), followed by a group of eight circuits with party differences in the $12 \%-17 \%$ range, followed by the $9^{\text {th }}$ circuit, which shows by far the largest party difference $(27 \%)$. There is also a modest tendency for party differences to be larger as the ideology of the circuit becomes more liberal (a correlation across circuits of .43 between the percentage of liberal votes and the size of the party difference). Larger party differences tend to be accompanied by larger panel differences as well - there is a correlation of .70 between the sizes of party and panel effects (the $6^{\text {th }}$ circuit, which has a 
large party effect but no panel effect, is the main exception to this pattern). Further, panel effects are generally about the same size as party effects (the only exceptions are the $5^{\text {th }}$ and $6^{\text {th }}$ Circuits), as we saw in our aggregate analysis above. In the great majority of circuits, a judge's vote is predicted as well or better by the political affiliation of the president who appointed the two other panel members as by the political affiliation of the president who appointed the judge in question.

Figure 7. Party and Panel Effects on Individual Judges' Votes, by Circuit (from smallest to largest party difference)

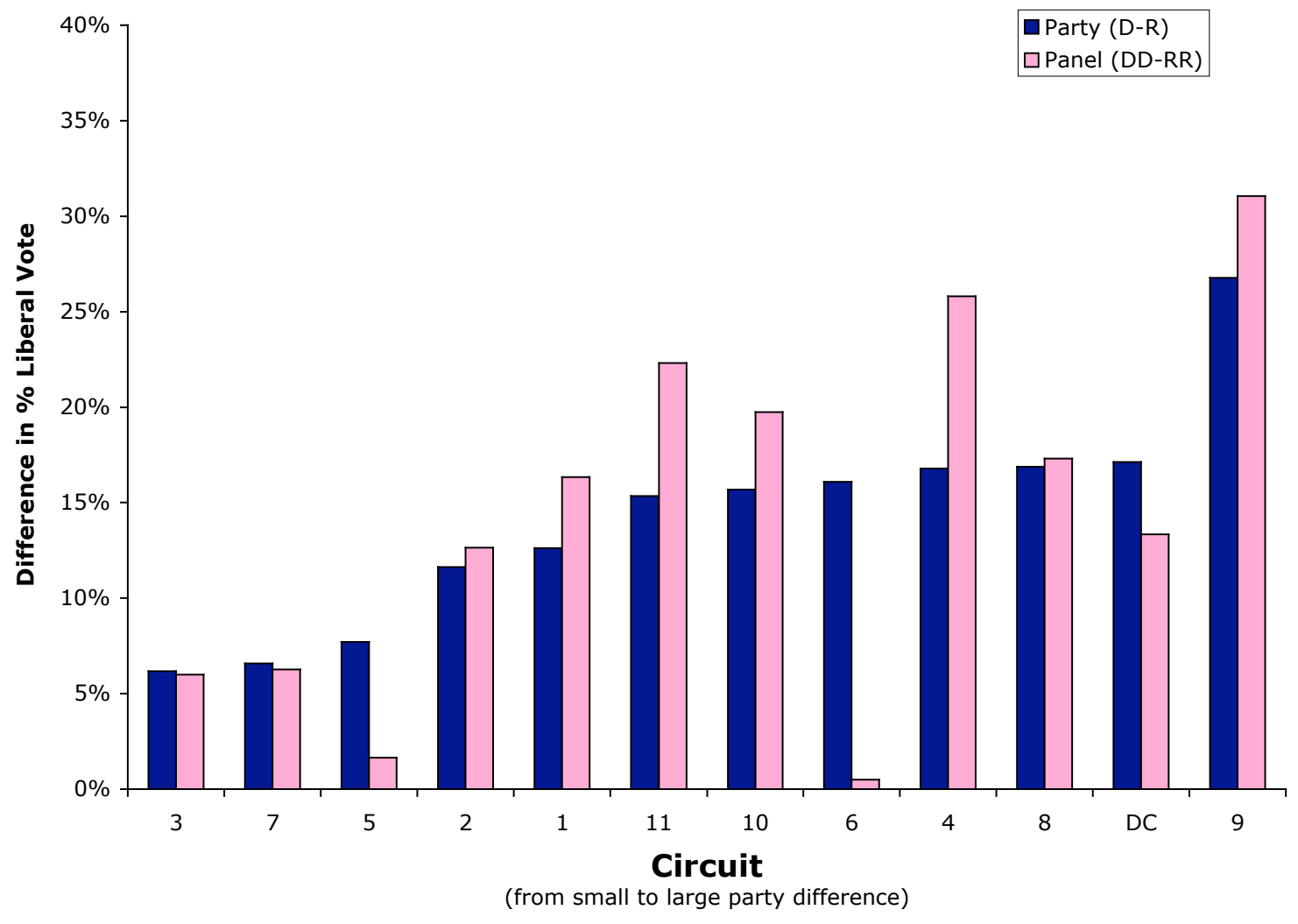




\section{Explanations}

What explains this pattern of outcomes? We sort them into three categories: those in which all three hypotheses are rejected; those in which party effects are clear, but unaccompanied by panel effects; and those in which all three hypotheses are confirmed.

\section{A. No Party Effects, No Panel Effects}

Consider first the contexts in which all three of our hypotheses are rejected. In those contexts, Republican and Democratic appointees do not much disagree, and hence the political party of the appointing judge will not affect outcomes. In many areas, ideology is undoubtedly irrelevant to judicial votes. For example, we would not expect to see significant party effects in diversity cases that present routine issues of state law. Our investigation finds that party is irrelevant in several areas where such effects might be anticipated (and indeed in which we anticipated them). By informal lore, Republican appointees and Democratic appointees do disagree in criminal appeals, takings, and federalism cases. But informal lore is wrong. There are two possible explanations.

The first explanation is that the law is clear and binding, and hence ideological disagreements cannot materialize. It is plausible to think that in all three areas, the precedents dampen any differences between Republican and Democratic appointees. At the court of appeals level, there might well be a sufficient consensus about the doctrine as to overcome the potential effects of party. Perhaps the disagreements can manifest themselves only in the "frontiers" cases - the highly unusual situations that find their way to the Supreme Court itself. This hypothesis finds some support in the commerce clause, where the small, statistically insignificant difference between Democratic and Republican appointees seems to come in these "frontiers" cases.

The second possibility is that even if the doctrine does allow courts room to maneuver, appointees of different parties do not much disagree about the appropriate principles. Other empirical work suggests that in criminal cases, Clinton appointees do not differ from Republican appointees. ${ }^{62}$ A near-consensus appears to exist in this area. Perhaps the same is true in the contexts of takings and federalism. For criminal appeals, there is a further point. Unlike in the civil context, criminal defendants will appeal even when there is no indeterminacy, because (with very rare exceptions) they are not paying for the appeal. As a result, most criminal appeals lack merit under the prevailing doctrine. ${ }^{63}$ Our data do not allow us to decide between the "binding precedent" and "ideological agreement" accounts. But they do show that in some domains where Democratic appointees and Republican appointees might be expected to differ, there is essential agreement.

\footnotetext{
${ }^{62}$ See Nancy Scherer, Are Clinton's Judges "Old" Democrats or "New" Democrats? 84 Judicature 151 (Nov.-Dec. 2000).

${ }^{63}$ Recall that many of the easiest cases are unpublished. But a large number of easy cases, in the criminal domain, also find their way into publication.
} 


\section{B. Party Effects Without Panel Effects}

What about the contexts of abortion and capital punishment? Here we find that party affiliation is what matters, and hence that people will vote their convictions regardless of the composition of the panel. In these cases, antecedent convictions must be extremely strong - strong enough to undo the group influences that occur in other types of cases. It seems clear that judges have strong beliefs about abortion and capital punishment, issues about which beliefs are often fiercely held. In cases of this kind, it is natural to assume that votes will be relatively impervious to panel effects. ${ }^{64}$

The disaggregated data show that for some judges, other areas have similar characteristics. On the D.C. Circuit, Democratic appointees respond to industry challenges to environmental regulations in the same way that judges as a whole respond to abortion and capital punishment cases: Party matters, but panel does not. In general, Sixth Circuit judges show the same pattern. On the Fifth Circuit, Republican appointees are unaffected by panel composition. One possibility is that the relevant judges have strong convictions across a range of cases, convictions that are sufficient to make panel irrelevant. Another possibility is that judges of the opposing party are particularly unconvincing. To understand this possibility, it is necessary to explore the reasons for panel effects.

\section{Why Aren't the Effects Larger?}

We have been emphasizing the existence of strong party and panel effects. But this is only part of the story. Even when party effects are significant, they are not overwhelmingly large. Recall that Republican appointees cast stereotypical liberal votes 34 percent of the time, whereas Democratic appointees do so 61 percent of the time. Over one-third of the votes of Democratic appointees are stereotypically conservative, and over one-third of the votes of Republican appointees are stereotypically liberal. More often than not, Republican and Democratic appointees agree with one another, even in the most controversial cases. Why is this?

We think that the answer has three parts. The first consists of panel effects. Republican appointees often sit with one or more Democratic appointees, and the same is true for Democratic appointees. If judges are influenced by one another, the random assignment of judges will inevitably produce some dampening of differences. The second factor involves the disciplining effect of precedent and law - a factor that might be labeled "professionalism." In the context of commerce clause challenges to legislation, we have explained judicial agreement across party lines partly on the ground that precedent is seen to dispose of most current disputes. Sometimes precedent will allow some, but not a great deal of, space for ideological differences to emerge. Undoubtedly the large measure of agreement is partly a product of the constraints of law itself. In some areas, those constraints will ensure that Republican and Democratic appointees do not

\footnotetext{
${ }^{64}$ See the discussion of how group influences are weakest in easy cases, when people have strong convictions, in Cass R. Sunstein, Why Societies Need Dissent (forthcoming 2003).
} 
disagree. In other areas, they will permit disagreement, but they will discipline its magnitude.

The third factor involves legal and political culture. For all of their differences, Democratic and Republican judicial appointees are almost never ideologues or extremists. If a sex discrimination plaintiff presents a strong claim, Republican appointees will agree with her, even if the law allows judges to exercise discretion; if an environmental regulation is plainly arbitrary, Democratic appointees will strike it down as arbitrary, even if the law would allow them to uphold it. The process of legal training imposes strong limits on what judges seek to do. In any case the political culture constrains presidential appointments, ensuring a kind of filtering that will, for the most part, prevent presidents from nominating (and the Senate from confirming) people whose views are extreme. The high levels of agreement between Republican and Democratic appointees are undoubtedly affected by this fact.

\section{Why Panel Effects?}

In our data, the usual pattern involves not simply party effects but also panel effects. Indeed, the latter are as large as the former, and sometimes larger. We observe substantial panel effects in the areas of campaign finance, affirmative action, disability discrimination, piercing the corporate veil, race discrimination, sexual harassment, sex discrimination, and judicial review of environmental regulations at the behest of industry plaintiffs. We suggest that three factors are probably at work.

1. The Collegial Concurrence. In the context of judicial review of environmental regulations, Dean Revesz's empirical analysis finds that “while individual ideology and panel composition both have important effects on a judge's vote, the ideology of one's colleagues is a better predictor of one's vote than one's own ideology." ${ }^{\prime 65}$ We have extended this finding to many domains. But why is "the ideology of one's colleagues" so influential? Let us begin by focusing on the difference between how a judge will vote, on a three-judge panel, if she sits with no colleagues from the same party, and how a judge will vote if she sits with one or more colleagues from the same party. The simplest explanation is that much of the time, judges are willing to offer a collegial concurrence.

Two factors are likely to contribute to the collegial concurrence. First, the votes of one's colleagues carry some information about what is right. If two colleagues believe that an affirmative action program is unconstitutional, and no other judge is available to argue on its behalf, then the exchange of arguments in the room will suggest that the program is genuinely unconstitutional. Second, dissenting opinions on a three-judge panel are likely to be both futile and burdensome to produce - a difficult combination. Most of the time, such dissents will not persuade either of the majority's judges to switch his vote. To be sure, such a dissent might, in extreme cases, attract the attention of the Supreme Court or lead to a rehearing en banc; and when judges dissent, it is partly in the hope that such an outcome will occur. But Supreme Court review is rare, and courts of

${ }^{65}$ Id. at 1764 (1997). 
appeals are most unlikely to rehear cases en banc. ${ }^{66}$ In any case, it is time-consuming to write a dissent. If the ultimate decision is not going to be affected, why do the extra work? There is a further point. Dissenting opinions might also cause a degree of tension among judges, a particular problem in light of the fact that judges must work together for many years. According to informal lore, a kind of implicit bargain is struck within many courts of appeals, in the form of, "I won't dissent from your opinions if you won't dissent from mine, at least not unless the disagreement is very great." All of these points help account for the great power of "the ideology of one's colleagues" in producing judicial votes.

We can better understand these points if we notice the clear connection between the collegial concurrence and the behavior of individuals, in experimental settings, when faced with a unanimous group opinion. A great deal of social science research has shown that if people are confronted with the unanimous views of others, they tend to yield. ${ }^{67}$ This finding has been made in the context of both political and legal issues, ${ }^{68}$ and it extends to simple issues of fact. ${ }^{69}$ Sometimes people yield even with respect to the unambiguous evidence of their own senses. The yielding, a form of collegial concurrence, occurs partly because of the information suggested by the unanimity of others; how could shared views be wrong? And it occurs partly because of reputational pressures; people do not want to stand out on a limb. The evidence here suggests that judges are vulnerable to similar influences. Note that an understanding of these points clarifies the failure of the second two hypotheses in the contexts of abortion and capital punishment. In those contexts, judgments are firmly held, and the firmness of those judgments is sufficient to outweigh the informational and reputational pressure imposed by the contrary judgments of panel members.

In fact, an understanding of the relevant processes helps to explain and refine the leveling effects that we have emphasized. Suppose that a Democratic appointee is sitting with two Republican appointees, and everyone on the panel knows that the Democratic appointee might reject an extreme ruling. The anticipation or threat of a dissent, or a separate opinion, might lead the two Republicans to moderate their decision so as to ensure unanimity. The collegial concurrence need not show that the isolated Democrat, or the isolated Republican, is simply going along with her peers. It might well be that the very presence of a potential dissenter has led to a mutually agreeable opinion; both sides might have done some yielding. Our data, focused on outcomes, does not enable us to test this hypothesis rigorously. But the sharp difference between divided and unified panels, in terms of expected votes, is at least suggestive about the possibly important effect of the isolated Democrat or Republican. It is to that difference that we now turn.

2. Group Polarization. Why do all-Republican panels, and all-Democratic panels, behave so distinctively? Why are they different from majority Republican panels and

\footnotetext{
${ }^{66}$ Explanation and data to be added.

${ }^{67}$ See the overview in Solomon Asch, Opinions and Social Pressure, in Readings About the Social Animal 13 (Elliott Aronson ed. 1995).

${ }^{68}$ See R.S. Crutchfield, Conformity and Character, 10 Am. Psych. 191 (1955).

${ }^{69}$ See Asch, supra note.
} 
majority Democratic panels? A clue comes from one of the most striking findings in modern social science, which finds that groups of like-minded people tend to go to extremes. ${ }^{70}$ More particularly, such groups end up taking a more extreme position in the same direction as their predeliberation tendencies. Outside of the judicial context, consider a few examples:

- A group of moderately profeminist women will become more strongly profeminist after discussion. $^{71}$

- After discussion, citizens of France become more critical of the United States and its intentions with respect to economic aid. ${ }^{72}$

- After discussion, whites predisposed to show racial prejudice offer more negative responses to the question whether white racism is responsible for conditions faced by African-Americans in American cities. ${ }^{73}$

- After discussion, whites predisposed not to show racial prejudice offer more positive responses to the same question. ${ }^{74}$

- Juries inclined to award punitive damages typically produce awards that are significantly higher than the awards of their median member. ${ }^{75}$

An understanding of group polarization strongly suggests that in an important sense, our findings about party and panel effects are understated. We have focused on votes - on who wins and who loses. We have not focused on opinions, which can be written narrowly or broadly. Investigation of the substance of the opinions would obviously be burdensome and involve considerable exercise of discretion. But it is entirely plausible to speculate that a unified panel is less likely to be moderate than a divided one - and hence that the extremism of all-Republican and all-Democratic panels is understated by an investigation that looks only at likely votes. There is much room here for further analysis.

There have been three main explanations for group polarization, all of which have been extensively investigated. ${ }^{76}$

a. Persuasive arguments. The first explanation, emphasizing the role of persuasive arguments, is based on a common sense intuition: that any individual's position on an issue is partly a function of which arguments presented within the group seem convincing. The choice therefore moves in the direction of the most persuasive position defended by the group, taken as a collectivity. Because a group whose members are already inclined to vote in a certain direction will have a disproportionate number of arguments supporting that same direction, the result of discussion will be to move individuals further in the direction of their initial inclinations. The key is the existence of

\footnotetext{
${ }^{70}$ See Roger Brown, Social Psychology: The Second Edition 203-226 (1985).

${ }^{71}$ See D.G. Myers, Discussion-Induced Attitude Polarization, 28 Human Relations 699 (1975).

72 Brown, supra note, at 224.

${ }^{73}$ D.G. Myers and G.D. Bishop, The Enhancement of Dominant Attitudes in Group Discussion, 20 J. Personality and Soc. Psych. 286 (1976).

${ }^{74}$ See id.

${ }^{75}$ See Schkade et al., supra note.

${ }^{76}$ See Brown, supra note.
} 
a limited argument pool, one that is skewed (speaking purely descriptively) in a particular direction. ${ }^{77}$

b. Social comparison. The second explanation, involving social comparison, begins with the claim that people want to be perceived favorably by other group members, and they want also to perceive themselves favorably. Once they hear what others believe, they adjust their positions in the direction of the dominant position. The result is to press the group's position toward one or another extreme, and also to induce shifts in individual members. ${ }^{78}$ People may wish, for example, not to seem too enthusiastic or too restrained in their enthusiasm for affirmative action, feminism, or an increase in national defense; hence their views may shift when they see what other group members think. The result will be group polarization.

c. The role of corroboration. The third explanation begins by noting that people with extreme views tend to have more confidence that they are right, and that as people gain confidence, they become more extreme in their beliefs. ${ }^{79}$ The basic idea here is simple: Those who lack confidence, and who are unsure what they should think, tend to moderate their views. It is for this reason that cautious people, not knowing what to do, are likely to choose the midpoint between relevant extremes. ${ }^{80}$ But if other people seem to share your view, you are likely to become more confident that you are correct - and hence to move in a more extreme direction. In a wide variety of experimental contexts, people's opinions have been shown to become more extreme simply because their view has been corroborated, and because they have been more confident after learning of the shared views of others. ${ }^{81}$

It seems reasonable to speculate that one of our key results - ideological amplification on all-Republican and all-Democratic panels - reflects group polarization. When a court consists of a panel of judges with the same basic orientation, the median view, before deliberation begins, will be significantly different from what it would be with a panel of diverse judges. The argument pool will be very different as well. For example, a panel of three Republican appointees, tentatively inclined to invalidate the action of the Environmental Protection Agency (EPA), will offer a range of arguments in support of invalidation and relatively few in the other direction - even if the law, properly interpreted, favors validation. If the panel contains a judge who is inclined to uphold the EPA, the arguments that favor validation are far more likely to emerge and to be pressed. Indeed, the very fact that the judge is a Democrat increases the likelihood that this will occur, since that judge might not think of himself as being part of the same "group" as the other panel members. And because corroboration of opinion leads to greater confidence and hence extremity, it is not surprising that deliberation by a panel of three like-minded judges would lead to unusual and extreme results.

\footnotetext{
${ }^{77}$ See id.

${ }^{78}$ Id; Sunstein, Why Societies Need Dissent, supra note.

${ }^{79}$ See Robert Baron et al., Social Corroboration and Opinion Extremity, 32 J. Experimental Soc. Psych. 537 (1996).

${ }^{80}$ See Mark Kelman et al., Context-Dependence in Legal Decision Making, 25 J. Legal Stud. 287, 287-88 (1996).

${ }^{81}$ Baron et al., supra note.
} 
In this context, the difference in voting patterns on unified and divided panels is fortified by the possibility that the minority judge, finding himself outnumbered, might produce a dissenting opinion in public. To be sure, Supreme Court review is rare and in the general run of cases, the prospect of such review probably does not have much of a deterrent effect on courts of appeals. But judges who write majority opinions are usually not enthusiastic about having to see and to respond to dissenting opinions. And if the law actually favors the dissenting view, two judges, even if they would like to reverse the Environmental Protection Agency, might be influenced to adopt the easier course of validation.

At this point a skeptic might note that lawyers make adversarial presentations before judges. Such a skeptic might insist that the size of the "argument pool" is determined by those presentations, not only and not even mostly by what members of the panel are inclined to say and to do. And undoubtedly the inclinations of judges are shaped, some of the time, by the contributions of advocates. But adversarial presentations are made before all panel compositions, and so they cannot explain panel effects. In any case what matters, for purposes of the outcomes, is the inclinations of judges, upon whatever they are based; and it is here that the existence of a unified rather than divided panel can make all the difference. Notice in this regard that for the polarization hypothesis to hold, it is not necessary to know whether judges spend a great deal of time offering reasons to one another. Mere exposure to a conclusion is enough. ${ }^{82}$ A system of simple votes, unaccompanied by reasons, should incline judges to polarize. Of course reasons, if they are good ones, are likely to make those votes especially persuasive.

3. The Whistleblower Effect. Imagine that existing law is not entirely clear, but that fairly applied, it requires one or another outcome. It is easily imaginable that likeminded judges, unaccompanied by a potential dissenter, will fail to apply the law fairly. This is not because they are essentially lawless. It is because when the law is unclear, fallible human beings might well be inclined to understand the law in a way that fits with their predilections.

These points provide a possible explanation for some of the differences between panels with two-to-one majorities and panels in which all judges were appointed by a president of the same political party. Consider affirmative action cases. In some of these cases, three Democratic appointees might well be inclined to vote in favor of validation even if existing doctrine argues the other way. If no Republican appointee is on the panel, there is a risk that the panel will unanimously support validation in the face of existing law. The effect of the Republican is to call the panel's attention to the tension between its inclination and the decided cases. Of course her effort may fail. Her copanelists might persist in their views, perhaps with the claim that those cases can be distinguished. But if existing law does create serious problems for the panel, the presence of a judge with a different inclination will have a large effect. We speculate that in the areas in which there is a large difference between two-to-one majorities and three judges from the same president, this effect - a whistleblower effect - is playing a role.

\footnotetext{
${ }^{82}$ See Robert Baron et al., supra note, at 74.
} 
Our data do not allow this speculation to be tested directly. But a separate study shows the importance of a potential dissenter, or whistleblower, in ensuring that courts follow the law. ${ }^{83}$ More particularly, a Democratic appointee, on a court of appeals panel, turns out to be extremely important in ensuring that such a panel does what the law asks it to do. The basic point is that diversity of view helps to correct errors - not that judges of one or another party are likely to be correct.

To understand this study, some background is in order. Under the Supreme Court's decision in Chevron v. NRDC, ${ }^{84}$ courts are supposed to uphold agency interpretations of law so long as the interpretations are "reasonable." But when do courts actually uphold such interpretations? Existing law allows judges considerable room to maneuver, so that courts that are inclined to invalidate agency interpretations usually can find a plausible basis for doing so. The real question is when they will claim to have found that plausible basis. The relevant study, extending well beyond environmental protection to regulation in general, confirms the idea that party affiliation has an exceedingly large influence on outcomes within the D.C. Circuit. If observers were to code cases very crudely, by taking account of whether industry or a public interest group is bringing the challenge, they would find that a majority of Republican appointees reaches a conservative judgment $54 \%$ of the time, whereas a majority of Democratic appointees reaches such a judgment merely $32 \%$ of the time. ${ }^{85}$

For present purposes, the most important finding is the dramatic difference between politically diverse panels, with judges appointed by Presidents of more than one party, and politically unified panels, with judges appointed by Presidents of only one party. On divided panels in which a Republican majority of the court might be expected, on broadly speaking political grounds, to be hostile to the agency, the court nonetheless upheld the agency's interpretation $62 \%$ of the time. But on unified panels in which an allRepublican panel might be expected to be hostile to the agency, the court upheld the agency's interpretation only $33 \%$ of the time. Note that this was the only unusual finding in the data. When Democratic majority courts were expected to uphold the agency's decision on political grounds, they did so over $70 \%$ of the time, whether unified $(71 \%$ of the time) or divided ( $86 \%$ of the time). Consider the results in tabular form ${ }^{86}$ :

\begin{tabular}{lcccc} 
& $\begin{array}{c}\text { RRR } \\
\text { panel }\end{array}$ & $\begin{array}{l}\text { RRD } \\
\text { panel }\end{array}$ & $\begin{array}{l}\text { RDD } \\
\text { panel }\end{array}$ & $\begin{array}{l}\text { DDD } \\
\text { panel }\end{array}$ \\
\cline { 2 - 5 } Uphold agency & $33 \%$ & $62 \%$ & $86 \%$ & $71 \%$ \\
$\begin{array}{l}\text { action } \\
\text { Invalidate }\end{array}$ & $67 \%$ & $38 \%$ & $14 \%$ & $29 \%$ \\
agency action & $67 \%$ & & &
\end{tabular}

\footnotetext{
${ }^{83}$ Frank Cross and Emerson Tiller, Judicial Partisanship and Obedience to Legal Doctrine, 107 Yale L.J. 2155 (1998).

${ }^{84}$ See 467 U.S. 837 (1984).

${ }^{85}$ Cross and Tiller, supra note, at 2169.

${ }^{86}$ Constructed on the basis of data in Cross and Tiller, supra note, at 2172-2173.
} 
It is reasonable to speculate that the seemingly bizarre result - a $67 \%$ invalidation rate when Republican appointees are unified! - reflects group influences and, in particular, group polarization. A group of all-Republican appointees might well take the relatively unusual step of rejecting an agency's interpretation. By contrast, a divided panel, with a built-in check on any tendency toward the unusual or extreme outcome, is more likely to take the conventional route of simply upholding the agency's action. An important reason is that the single Democratic appointee acts as a "whistleblower," discouraging the other judges from making a decision that is inconsistent with the Supreme Court's command that courts of appeals should uphold agency interpretations of ambiguous statutes. $^{87}$

\section{E. A Preliminary Investigation - and Future Directions}

We have emphasized that this is a preliminary investigation. It should be possible, before terribly long, to do what we have done here for multiple domains of the law, extending over time. The data are readily available and most of the work involves mere counting. As we have suggested, it would be exceedingly interesting to know whether the three hypotheses hold in the pre-New Deal tensions between courts and the regulatory state and in the struggle over school segregation. So, too, it would be valuable to know whether similar patterns can be found in the legal disputes over slavery, in judicial review of decisions by the National Labor Relations Board and the Federal Communications Commission, in cases brought under the Federal Tort Claims Act, and in cases involving foreign affairs and war.

We could easily imagine that ideological disagreements, between judges appointed by presidents of different parties, would be greater or weaker in certain historical periods. It might be hypothesized, for example, that such disagreements were weakened in the 1940s, when the nation seemed to form a consensus about the appropriate role of the federal judiciary. It might also be hypothesized that such disagreements would be especially strong since 1980, with powerful partisan divisions about the appropriate role of the federal judiciary. But are these hypotheses correct? Ultimately it would be desirable to compile an extensive data set about votes on federal courts of appeals, showing the diverse patterns into which those votes fall.

\section{What Should Be Done?}

It remains to investigate the normative issues. Is it troubling to find a large effect from party or from panel composition? Should we be concerned if like-minded judges go to extremes? Is there reason to attempt to ensure diversity on the federal courts? To promote a degree of diversity on panels? There is a widespread view that judges appointed by presidents of different political parties are not fundamentally different and that, once on the bench, judges frequently surprise those who nominated them. ${ }^{88}$ The view is not entirely baseless, but it is misleading. Some appointees do disappoint the Presidents who nominated them, but these examples are not typical. Judges appointed by

\footnotetext{
${ }^{87}$ See id. at 2174-76.

${ }^{88}$ See, e.g., Jeffrey Rosen, New York Times Magazine; others.
} 
Republican presidents are quite different from judges appointed by Democratic presidents. To take evidence from just one area, "[p]artisanship clearly affects how appellate courts review agency discretion. ${ }^{89}$ We have noted that the effects that we find are large but not massive. Because of the disciplining effect of precedent, and because judges do not radically disagree with one another, there is significant commonality across political party. But in the most difficult areas, the ones where the law is unclear or in flux, both party and panel effects are large enough to be a source of serious concern.

It is difficult to evaluate the underlying issues without taking a stand on the merits - without knowing what we want judges to do. Suppose that three Republican appointees are especially likely to strike down affirmative action programs, and that three Democratic appointees are especially likely to uphold those programs. At first glance, one or the other inclination is troubling only if we know whether we approve of one or another set of results. And if a view about what judges should do is the only possible basis for evaluation, we might conclude that those who prefer judges of a particular party should seek judges of that party, and that group influences are essentially beside the point.

But the conclusion is too strong. In some cases, the law, properly interpreted, really does argue strongly for one or another view. The existence of diversity on a panel is likely to bring that fact to light and perhaps to move the panel's decision in the direction of what the law requires. The existence of politically diverse judges, and of a potential dissent, increases the probability that the law will be followed. The Chevron study, referred to above, strongly supports this point. ${ }^{90}$ The presence of a potential dissenter - in the form of a judge appointed by a president from another political party creates a possible whistleblower who can reduce the likelihood of an incorrect or lawless decision. ${ }^{91}$ Through an appreciation of the nature of group influences, we can see the wisdom in an old idea: A decision is more likely to be right, and less likely to be political in a pejorative sense, if it is supported by judges with different predilections.

There is a further point. Suppose that in many areas, it is not clear, in advance, whether the appointees of Democratic or Republican presidents are correct. Suppose that we are genuinely uncertain. If so, then there is reason to favor a situation in which the legal system has both, simply on the ground that through that route, more reasonable opinions are likely to be heard. And if we are genuinely uncertain, then there is reason to favor a mix of views merely by virtue of its moderating effect. In the face of uncertainty, sensible people choose between the poles. ${ }^{92}$

Consider an analogy. Independent regulatory commissions, such as the Federal Trade Commission, the Securities and Exchange Commission, the National Labor Relations Board, and the Federal Communications Commission, often make modern law

\footnotetext{
${ }^{89}$ See Revesz, supra note, at 2175.

${ }^{90}$ See Cross and Tiller, supra note.

${ }^{91}$ This is the explanation in Cross and Tiller, supra note, at 2173.

${ }^{92}$ For evidence, see Mark Kelman et al., Context-Independence in Legal Decisionmaking, in Behavioral Law and Economics (Cass R. Sunstein ed. 2000).
} 
and policy. Much of the time, such agencies act through adjudication. They function in the same fashion as federal courts. And under federal statutes, Congress has attempted to ensure that these agencies are not monopolized by either Democratic appointees or Republican appointees. The law requires that no more than a bare majority of agency members may be from a single party. ${ }^{93}$ An understanding of group influences helps to explain this requirement. An independent agency that is all-Democratic, or allRepublican, might move toward an extreme position, indeed toward a position that is more extreme than that of the median Democrat or Republican, and possibly more extreme than that of any agency official standing alone. A requirement of bipartisan membership can operate as a check against movements of this kind. Congress was apparently aware of this general point. Closely attuned to the policymaking functions of the relevant institutions, it was careful to provide a safeguard against extreme movements.

Why do we fail to create similar safeguards for courts? Part of the answer must lie in a belief that unlike heads of independent regulatory commissions, judges are not policymakers. Their duty is to follow the law, not to make policy. An attempt to ensure bipartisan composition would seem inconsistent with the commitment to this belief. But the evidence we have discussed shows that judges are policymakers of an important kind, and that their political commitments very much influence their votes. In principle, there is good reason to attempt to ensure a mix of perspectives within courts of appeals.

Of course the idea of diversity, or of a mix of perspectives, is hardly self-defining. It would not be appropriate to say that the federal judiciary should include people who refuse to obey the Constitution, or who refuse to exercise the power of judicial review, or who think that the Constitution allows suppression of political dissent and racial segregation. Here as elsewhere, the domain of appropriate diversity is limited. What is necessary is reasonable diversity, or diversity of reasonable views, and not diversity as such. People can certainly disagree about what reasonable diversity entails in this context. We are suggesting here that there is such a thing as reasonable diversity, and that it is important to ensure that judges, no less than anyone else, are exposed to it, and not merely through the arguments of advocates.

These points cast fresh light on a much disputed issue: the legitimate role of the Senate in giving "advice and consent" to presidential appointments to the federal judiciary. Above all, an understanding of social influences suggests that the Senate has a responsibility to exercise its constitutional authority in order to ensure a reasonable diversity of views. The Constitution's history fully contemplates an independent role for the Senate in the selection of Supreme Court Justices. ${ }^{94}$ That independent role certainly authorizes the Senate to consider the general approach, and the likely pattern of votes, of potential judges. There can be no doubt that the President considers the general approach of his nominees; the Senate is entitled to do so as well. Under good conditions, these simultaneous powers would bring about a healthy form of checks and balances,

\footnotetext{
${ }^{93}$ See, e.g., 15 U.S.C. $§ 78 d$ (1994).

${ }^{94}$ See David A. Strauss and Cass R. Sunstein, The Senate, the Constitution, and the Confirmation Process, 101 Yale L.J. 1491 (1992).
} 
permitting each branch to counter the other. Indeed, that system is part and parcel of social deliberation about the direction of the federal judiciary.

Why might this view be rejected? It could be urged that there is only one legitimate approach to constitutional or statutory interpretation - that, for example, some version of originalism or textualism is the only such approach, and that anyone who rejects that view is unreasonable. For true believers, it is pointless to argue for diverse views. ${ }^{95}$ Diversity is not necessary, or even valuable, if we already know what should be done, and if competing views would simply cloud the issue. (In a scientific dispute, it is not helpful to include those who believe that the earth is flat.) Or it might be urged that a deferential role for the Senate, combined with natural political competition and cycles, will produce a sensible mix over time. We do not deny this possibility. Our only suggestions are that a high degree of diversity on the federal judiciary is desirable, that the Senate is entitled to pursue diversity, and that without such diversity, judicial panels are will inevitably go in unjustified directions.

\section{Conclusion}

No reasonable person seriously doubts that ideology, understood as normative commitments of various sorts, helps to explain judicial votes. Presidents are entirely aware of this point, and their appointment decisions are undertaken with full appreciation of it. We have found striking evidence of a relationship between the political party of the appointing president and judicial voting patterns. We have also found that much of the time, judicial votes are affected by panel composition. In many domains, the voting patterns of isolated Democratic appointees are close to what would be expected from the median Republican appointee, just as the voting patterns of an isolated Republican appointee are akin to what would be expected from the median Democratic appointee. In many domains, a Democratic appointee is significantly more likely to vote in the stereotypical liberal fashion if surrounded by two Democratic appointees than if surrounded by one Republican and one Democrat. So too for Republican appointees, whose voting patterns are very much influenced by having two, rather than one, copanelists appointed by a president of the same political party.

Taken as a whole, the data suggest the pervasiveness of three phenomena. The first is the collegial concurrence: votes to join two colleagues and to refuse to dissent publicly, notwithstanding an initial disposition to vote the other way and very possibly, a continuing belief that the decision is incorrect. The second is group polarization: the tendency, within a group of like-minded people, to move to relative extremes. The third is a whistleblower effect, by which a single judge, of a different party from the majority, can have a moderating effect on a judicial panel.

\footnotetext{
${ }^{95}$ Note, however, that even if it would be appropriate for all judges to share a certain approach, it is also desirable to have diversity with respect to the application of that approach. Textualists do not all agree with one another; there is internal diversity in the world of originalism. Diversity is appropriate here to ensure an airing of reasonable views.
} 
It might be surprising to find that in some controversial areas, the political affiliation of the appointing president is not correlated with judicial votes, and hence that in those areas, none of these effects can be observed. This is the basic finding for criminal appeals, takings, and federalism. But it should not be terribly surprising to see that in the areas of abortion and capital punishment, judges vote their convictions. Here the political affiliation of the appointing president is crucial, but panel composition is otherwise irrelevant. What is perhaps most striking is that in our data set, abortion and capital punishment are the only areas in which ideology matters but panel composition does not.

These findings do not have uncontroversial implications for the composition of panels or of the judiciary as a whole. But if divided panels increase the likelihood of effective whistleblowing, and if unified panels tend to go to extremes, there is fresh reason to attempt to ensure a high degree of intellectual diversity within the federal courts and even within judicial panels. Of course this claim would not hold if the appointees of one or another party had a monopoly on legal wisdom. In most areas, however, we think that there is no such monopoly, and that better results are likely to come from a mix of views and inclinations. However the normative issues are resolved, the empirical findings are clear. In many domains, Republican appointees vote very differently from Democratic appointees, and the effects of ideology are both dampened and amplified by the composition of the panel. 


\section{Appendix: Overall Logistic Regression Results}

$\mathrm{DV}=$ Liberal vote $(0,1)$

\begin{tabular}{lrrrr} 
Predictor & Coefficient & Std. Error & \multicolumn{1}{c}{$\mathrm{Z}$} & $\mathrm{P}>|\mathrm{z}|$ \\
\hline Party (1 = Democratic appointee) & .576 & .074 & 7.81 & .000 \\
Other Two (\# Democrat appointees) & .285 & .046 & 6.19 & .000 \\
Party * Other Two & .126 & .068 & 1.86 & .063 \\
ADA & -1.144 & .110 & -10.41 & .000 \\
Abortion & -.028 & .155 & -.18 & .859 \\
Campaign Finance & -.997 & .194 & -5.13 & .000 \\
Capital Punishment & -1.226 & .139 & -8.82 & .000 \\
Contracts & -1.517 & .184 & -8.24 & .000 \\
Pierce Corp Veil & -1.176 & .159 & -7.40 & .000 \\
Environmental protection & -.065 & .198 & -.33 & .743 \\
Sex Discrimination & -.656 & .106 & -6.21 & .000 \\
Title VII & -.799 & .120 & -6.66 & .000 \\
1st Circuit & -.347 & .121 & -2.87 & .004 \\
2nd Circuit & -.321 & .112 & -2.87 & .004 \\
3rd Circuit & .262 & .132 & 1.98 & .047 \\
4th Circuit & -.638 & .126 & -5.06 & .000 \\
5th Circuit & -.928 & .113 & -8.21 & .000 \\
6th Circuit & -.584 & .111 & -5.28 & .000 \\
7th Circuit & -.695 & .101 & -6.89 & .000 \\
8th Circuit & -.567 & .099 & -5.74 & .000 \\
10th Circuit & -.472 & .118 & -4.01 & .000 \\
11th Circuit & -.590 & .117 & -5.06 & .000 \\
12th Circuit & -.636 & .167 & -3.80 & .000 \\
Constant & .331 & .131 & 2.53 & .011
\end{tabular}

Base case $($ constant $)=9$ th circuit, affirmative action cases, Republican

Number of obs $=8475$

LR chi2(23) $=747.63$

Prob $>$ chi $2=0.0000$

Pseudo R2 = 0.0657

Log likelihood $=-5318.8336$ 
Readers with comments should address them to:

\section{Cass R. Sunstein}

University of Chicago Law School

1111 East 60th Street

Chicago, IL 60637

csunstei@midway.uchicago.edu 


\section{Chicago Working Papers in Law and Economics}

(Second Series)

1. William M. Landes, Copyright Protection of Letters, Diaries and Other Unpublished Works: An Economic Approach (July 1991)

2. Richard A. Epstein, The Path to The T. J. Hooper: The Theory and History of Custom in the Law of Tort (August 1991)

3. Cass R. Sunstein, On Property and Constitutionalism (September 1991)

4. Richard A. Posner, Blackmail, Privacy, and Freedom of Contract (February 1992)

5. Randal C. Picker, Security Interests, Misbehavior, and Common Pools (February 1992)

6. Tomas J. Philipson \& Richard A. Posner, Optimal Regulation of AIDS (April 1992)

7. Douglas G. Baird, Revisiting Auctions in Chapter 11 (April 1992)

8. William M. Landes, Sequential versus Unitary Trials: An Economic Analysis (July 1992)

9. William M. Landes \& Richard A. Posner, The Influence of Economics on Law: A Quantitative Study (August 1992)

10. Alan O. Sykes, The Welfare Economics of Immigration Law: A Theoretical Survey With An Analysis of U.S. Policy (September 1992)

11. Douglas G. Baird, 1992 Katz Lecture: Reconstructing Contracts (November 1992)

12. Gary S. Becker, The Economic Way of Looking at Life (January 1993)

13. J. Mark Ramseyer, Credibly Committing to Efficiency Wages: Cotton Spinning Cartels in Imperial Japan (March 1993)

14. Cass R. Sunstein, Endogenous Preferences, Environmental Law (April 1993)

15. Richard A. Posner, What Do Judges and Justices Maximize? (The Same Thing Everyone Else Does) (April 1993)

16. Lucian Arye Bebchuk and Randal C. Picker, Bankruptcy Rules, Managerial Entrenchment, and Firm-Specific Human Capital (August 1993)

17. J. Mark Ramseyer, Explicit Reasons for Implicit Contracts: The Legal Logic to the Japanese Main Bank System (August 1993)

18. William M. Landes and Richard A. Posner, The Economics of Anticipatory Adjudication (September 1993)

19. Kenneth W. Dam, The Economic Underpinnings of Patent Law (September 1993)

20. Alan O. Sykes, An Introduction to Regression Analysis (October 1993)

21. Richard A. Epstein, The Ubiquity of the Benefit Principle (March 1994)

22. Randal C. Picker, An Introduction to Game Theory and the Law (June 1994)

23. William M. Landes, Counterclaims: An Economic Analysis (June 1994)

24. J. Mark Ramseyer, The Market for Children: Evidence from Early Modern Japan (August 1994)

25. Robert H. Gertner and Geoffrey P. Miller, Settlement Escrows (August 1994)

26. Kenneth W. Dam, Some Economic Considerations in the Intellectual Property Protection of Software (August 1994)

27. Cass R. Sunstein, Rules and Rulelessness, (October 1994) 
28. David Friedman, More Justice for Less Money: A Step Beyond Cimino (December 1994)

29. Daniel Shaviro, Budget Deficits and the Intergenerational Distribution of Lifetime Consumption (January 1995)

30. Douglas G. Baird, The Law and Economics of Contract Damages (February 1995)

31. Daniel Kessler, Thomas Meites, and Geoffrey P. Miller, Explaining Deviations from the Fifty Percent Rule: A Multimodal Approach to the Selection of Cases for Litigation (March 1995)

32. Geoffrey P. Miller, Das Kapital: Solvency Regulation of the American Business Enterprise (April 1995)

33. Richard Craswell, Freedom of Contract (August 1995)

34. J. Mark Ramseyer, Public Choice (November 1995)

35. Kenneth W. Dam, Intellectual Property in an Age of Software and Biotechnology (November 1995)

36. Cass R. Sunstein, Social Norms and Social Roles (January 1996)

37. J. Mark Ramseyer and Eric B. Rasmusen, Judicial Independence in Civil Law Regimes: Econometrics from Japan (January 1996)

38. Richard A. Epstein, Transaction Costs and Property Rights: Or Do Good Fences Make Good Neighbors? (March 1996)

39. Cass R. Sunstein, The Cost-Benefit State (May 1996)

40. William M. Landes and Richard A. Posner, The Economics of Legal Disputes Over the Ownership of Works of Art and Other Collectibles (July 1996)

41. John R. Lott, Jr. and David B. Mustard, Crime, Deterrence, and Right-to-Carry Concealed Handguns (August 1996)

42. Cass R. Sunstein, Health-Health Tradeoffs (September 1996)

43. G. Baird, The Hidden Virtues of Chapter 11: An Overview of the Law and Economics of Financially Distressed Firms (March 1997)

44. Richard A. Posner, Community, Wealth, and Equality (March 1997)

45. William M. Landes, The Art of Law and Economics: An Autobiographical Essay (March 1997)

46. Cass R. Sunstein, Behavioral Analysis of Law (April 1997)

47. John R. Lott, Jr. and Kermit Daniel, Term Limits and Electoral Competitiveness: Evidence from California's State Legislative Races (May 1997)

48. Randal C. Picker, Simple Games in a Complex World: A Generative Approach to the Adoption of Norms (June 1997)

49. Richard A. Epstein, Contracts Small and Contracts Large: Contract Law through the Lens of Laissez-Faire (August 1997)

50. Cass R. Sunstein, Daniel Kahneman, and David Schkade, Assessing Punitive Damages (with Notes on Cognition and Valuation in Law) (December 1997)

51. William M. Landes, Lawrence Lessig, and Michael E. Solimine, Judicial Influence: A Citation Analysis of Federal Courts of Appeals Judges (January 1998)

52. John R. Lott, Jr., A Simple Explanation for Why Campaign Expenditures are Increasing: The Government is Getting Bigger (February 1998) 
53. Richard A. Posner, Values and Consequences: An Introduction to Economic Analysis of Law (March 1998)

54. Denise DiPasquale and Edward L. Glaeser, Incentives and Social Capital: Are Homeowners Better Citizens? (April 1998)

55. Christine Jolls, Cass R. Sunstein, and Richard Thaler, A Behavioral Approach to Law and Economics (May 1998)

56. John R. Lott, Jr., Does a Helping Hand Put Others At Risk?: Affirmative Action, Police Departments, and Crime (May 1998)

57. Cass R. Sunstein and Edna Ullmann-Margalit, Second-Order Decisions (June 1998)

58. Jonathan M. Karpoff and John R. Lott, Jr., Punitive Damages: Their Determinants, Effects on Firm Value, and the Impact of Supreme Court and Congressional Attempts to Limit Awards (July 1998)

59. Kenneth W. Dam, Self-Help in the Digital Jungle (August 1998)

60. John R. Lott, Jr., How Dramatically Did Women's Suffrage Change the Size and Scope of Government? (September 1998)

61. Kevin A. Kordana and Eric A. Posner, A Positive Theory of Chapter 11 (October 1998)

62. David A. Weisbach, Line Drawing, Doctrine, and Efficiency in the Tax Law (November 1998)

63. Jack L. Goldsmith and Eric A. Posner, A Theory of Customary International Law (November 1998)

64. John R. Lott, Jr., Public Schooling, Indoctrination, and Totalitarianism (December 1998)

65. Cass R. Sunstein, Private Broadcasters and the Public Interest: Notes Toward A "Third Way" (January 1999)

66. Richard A. Posner, An Economic Approach to the Law of Evidence (February 1999)

67. Yannis Bakos, Erik Brynjolfsson, Douglas Lichtman, Shared Information Goods (February 1999)

68. Kenneth W. Dam, Intellectual Property and the Academic Enterprise (February 1999)

69. Gertrud M. Fremling and Richard A. Posner, Status Signaling and the Law, with Particular Application to Sexual Harassment (March 1999)

70. Cass R. Sunstein, Must Formalism Be Defended Empirically? (March 1999)

71. Jonathan M. Karpoff, John R. Lott, Jr., and Graeme Rankine, Environmental Violations, Legal Penalties, and Reputation Costs (March 1999)

72. Matthew D. Adler and Eric A. Posner, Rethinking Cost-Benefit Analysis (April 1999)

73. John R. Lott, Jr. and William M. Landes, Multiple Victim Public Shooting, Bombings, and Right-to-Carry Concealed Handgun Laws: Contrasting Private and Public Law Enforcement (April 1999)

74. Lisa Bernstein, The Questionable Empirical Basis of Article 2's Incorporation Strategy: A Preliminary Study (May 1999) 
75. Richard A. Epstein, Deconstructing Privacy: and Putting It Back Together Again (May 1999)

76. William M. Landes, Winning the Art Lottery: The Economic Returns to the Ganz Collection (May 1999)

77. Cass R. Sunstein, David Schkade, and Daniel Kahneman, Do People Want Optimal Deterrence? (June 1999)

78. Tomas J. Philipson and Richard A. Posner, The Long-Run Growth in Obesity as a Function of Technological Change (June 1999)

79. David A. Weisbach, Ironing Out the Flat Tax (August 1999)

80. Eric A. Posner, A Theory of Contract Law under Conditions of Radical Judicial Error (August 1999)

81. David Schkade, Cass R. Sunstein, and Daniel Kahneman, Are Juries Less Erratic than Individuals? Deliberation, Polarization, and Punitive Damages (September 1999)

82. Cass R. Sunstein, Nondelegation Canons (September 1999)

83. Richard A. Posner, The Theory and Practice of Citations Analysis, with Special Reference to Law and Economics (September 1999)

84. Randal C. Picker, Regulating Network Industries: A Look at Intel (October 1999)

85. Cass R. Sunstein, Cognition and Cost-Benefit Analysis (October 1999)

86. Douglas G. Baird and Edward R. Morrison, Optimal Timing and Legal Decisionmaking: The Case of the Liquidation Decision in Bankruptcy (October 1999)

87. Gertrud M. Fremling and Richard A. Posner, Market Signaling of Personal Characteristics (November 1999)

88. Matthew D. Adler and Eric A. Posner, Implementing Cost-Benefit Analysis When Preferences Are Distorted (November 1999)

89. Richard A. Posner, Orwell versus Huxley: Economics, Technology, Privacy, and Satire (November 1999)

90. David A. Weisbach, Should the Tax Law Require Current Accrual of Interest on Derivative Financial Instruments? (December 1999)

91. Cass R. Sunstein, The Law of Group Polarization (December 1999)

92. Eric A. Posner, Agency Models in Law and Economics (January 2000)

93. Karen Eggleston, Eric A. Posner, and Richard Zeckhauser, Simplicity and Complexity in Contracts (January 2000)

94. Douglas G. Baird and Robert K. Rasmussen, Boyd's Legacy and Blackstone's Ghost (February 2000)

95. David Schkade, Cass R. Sunstein, Daniel Kahneman, Deliberating about Dollars: The Severity Shift (February 2000)

96. Richard A. Posner and Eric B. Rasmusen, Creating and Enforcing Norms, with Special Reference to Sanctions (March 2000)

97. Douglas Lichtman, Property Rights in Emerging Platform Technologies (April 2000) 
98. Cass R. Sunstein and Edna Ullmann-Margalit, Solidarity in Consumption (May 2000)

99. David A. Weisbach, An Economic Analysis of Anti-Tax Avoidance Laws (May 2000, revised May 2002)

100. Cass R. Sunstein, Human Behavior and the Law of Work (June 2000)

101. William M. Landes and Richard A. Posner, Harmless Error (June 2000)

102. Robert H. Frank and Cass R. Sunstein, Cost-Benefit Analysis and Relative Position (August 2000)

103. Eric A. Posner, Law and the Emotions (September 2000)

104. Cass R. Sunstein, Cost-Benefit Default Principles (October 2000)

105. Jack Goldsmith and Alan Sykes, The Dormant Commerce Clause and the Internet (November 2000)

106. Richard A. Posner, Antitrust in the New Economy (November 2000)

107. Douglas Lichtman, Scott Baker, and Kate Kraus, Strategic Disclosure in the Patent System (November 2000)

108. Jack L. Goldsmith and Eric A. Posner, Moral and Legal Rhetoric in International Relations: A Rational Choice Perspective (November 2000)

109. William Meadow and Cass R. Sunstein, Statistics, Not Experts (December 2000)

110. Saul Levmore, Conjunction and Aggregation (December 2000)

111. Saul Levmore, Puzzling Stock Options and Compensation Norms (December 2000)

112. Richard A. Epstein and Alan O. Sykes, The Assault on Managed Care: Vicarious Liability, Class Actions and the Patient's Bill of Rights (December 2000)

113. William M. Landes, Copyright, Borrowed Images and Appropriation Art: An Economic Approach (December 2000)

114. Cass R. Sunstein, Switching the Default Rule (January 2001)

115. George G. Triantis, Financial Contract Design in the World of Venture Capital (January 2001)

116. Jack Goldsmith, Statutory Foreign Affairs Preemption (February 2001)

117. Richard Hynes and Eric A. Posner, The Law and Economics of Consumer Finance (February 2001)

118. Cass R. Sunstein, Academic Fads and Fashions (with Special Reference to Law) (March 2001)

119. Eric A. Posner, Controlling Agencies with Cost-Benefit Analysis: A Positive Political Theory Perspective (April 2001)

120. Douglas G. Baird, Does Bogart Still Get Scale? Rights of Publicity in the Digital Age (April 2001)

121. Douglas G. Baird and Robert K. Rasmussen, Control Rights, Priority Rights and the Conceptual Foundations of Corporate Reorganization (April 2001)

122. David A. Weisbach, Ten Truths about Tax Shelters (May 2001)

123. William M. Landes, What Has the Visual Arts Rights Act of 1990 Accomplished? (May 2001)

124. Cass R. Sunstein, Social and Economic Rights? Lessons from South Africa (May 2001) 
125. Christopher Avery, Christine Jolls, Richard A. Posner, and Alvin E. Roth, The Market for Federal Judicial Law Clerks (June 2001)

126. Douglas G. Baird and Edward R. Morrison, Bankruptcy Decision Making (June 2001)

127. Cass R. Sunstein, Regulating Risks after ATA (June 2001)

128. Cass R. Sunstein, The Laws of Fear (June 2001)

129. Richard A. Epstein, In and Out of Public Solution: The Hidden Perils of Property Transfer (July 2001)

130. Randal C. Picker, Pursuing a Remedy in Microsoft: The Declining Need for Centralized Coordination in a Networked World (July 2001)

131. Cass R. Sunstein, Daniel Kahneman, David Schkade, and Ilana Ritov, Predictably Incoherent Judgments (July 2001)

132. Eric A. Posner, Courts Should Not Enforce Government Contracts (August 2001)

133. Lisa Bernstein, Private Commercial Law in the Cotton Industry: Creating Cooperation through Rules, Norms, and Institutions (August 2001)

134. Richard A. Epstein, The Allocation of the Commons:Parking and Stopping on the Commons (August 2001)

135. Cass R. Sunstein, The Arithmetic of Arsenic (September 2001)

136. Eric A. Posner, Richard Hynes, and Anup Malani, The Political Economy of Property Exemption Laws (September 2001)

137. Eric A. Posner and George G. Triantis, Covenants Not to Compete from an Incomplete Contracts Perspective (September 2001)

138. Cass R. Sunstein, Probability Neglect: Emptions, Worst Cases, and Law (November 2001)

139. Randall S. Kroszner and Philip E. Strahan, Throwing Good Money after Bad? Board Connections and Conflicts in Bank Lending (December 2001)

140. Alan O. Sykes, TRIPs, Pharmaceuticals, Developing Countries, and the Doha "Solution" (February 2002)

141. Edna Ullmann-Margalit and Cass R. Sunstein, Inequality and Indignation (February 2002)

142. Daniel N. Shaviro and David A. Weisbach, The Fifth Circuit Gets It Wrong in Compaq v. Commissioner (February 2002) (Published in Tax Notes, January 28, 2002)

143. Warren F. Schwartz and Alan O. Sykes, The Economic Structure of Renegotiation and Dispute Resolution in the WTO/GATT System (March 2002, Journal of Legal Studies 2002)

144. Richard A. Epstein, HIPAA on Privacy: Its Unintended and Intended Consequences (March 2002, forthcoming Cato Journal, summer 2002)

145. David A. Weisbach, Thinking Ouside the Little Boxes (March 2002, Texas Law Review)

146. Eric A. Posner, Economic Analysis of Contract Law after Three Decades: Success or Failure (March 2002)

147. Randal C. Picker, Copyright as Entry Policy: The Case of Digital Distribution (April 2002, The Antitrust Bulletin) 
148. David A. Weisbach, Taxes and Torts in the Redistribution of Income (April 2002, Coase Lecture February 2002)

149. Cass R. Sunstein, Beyond the Precautionary Principle (April 2002)

150. Robert W. Hahn and Cass R. Sunstein, A New Executive Order for Improving Federal Regulation? Deeper and Wider Cost-Benefit Analysis (April 2002)

151. Douglas Lichtman, Copyright as a Rule of Evidence (May 2002, updated January 2003)

152. Richard A. Epstein, Steady the Course: Property Rights in Genetic Material (May 2002)

153. Jack Goldsmith and Cass R. Sunstein, Military Tribunals and Legal Culture: What a Difference Sixty Years Makes (June 2002)

154. William M. Landes and Richard A. Posner, Indefinitely Renewable Copyright (July 2002)

155. Anne Gron and Alan O. Sykes, Terrorism and Insurance Markets: A Role for the Government as Insurer? (July 2002)

156. Cass R. Sunstein and Adrian Vermeule, Interpretation and Institutions (July 2002)

157. Cass R. Sunstein, The Rights of Animals: A Very Short Primer (August 2002)

158. Cass R. Sunstein, Avoiding Absurdity? A New Canon in Regulatory Law (with Notes on Interpretive Theory) (August 2002)

159. Randal C. Picker, From Edison to the Broadcast Flag: Mechanisms of Consent and Refusal and the Propertization of Copyright (September 2002)

160. Eric A. Posner, A Theory of the Laws of War (September 2002)

161 Eric A. Posner, Probability Errors: Some Positive and Normative Implications for Tort and Contract Law (September 2002)

162. Lior Jacob Strahilevitz, Charismatic Code, Social Norms, and the Emergence of Cooperation on the File-Swapping Networks (September 2002)

163. David A. Weisbach, Does the X-Tax Mark the Spot? (September 2002)

164. Cass R. Sunstein, Conformity and Dissent (September 2002)

165. Cass R. Sunstein, Hazardous Heuristics (October 2002)

166. Douglas Lichtman, Uncertainty and the Standard for Preliminary Relief (October 2002)

167. Edward T. Swaine, Rational Custom (November 2002)

168. Julie Roin, Truth in Government: Beyond the Tax Expenditure Budget (November 2002)

169. Avraham D. Tabbach, Criminal Behavior, Sanctions, and Income Taxation: An Economic Analysis (November 2002)

170. Richard A. Epstein, In Defense of "Old" Public Health: The Legal Framework for the Regulation of Public Health (December 2002)

171. Richard A. Epstein, Animals as Objects, or Subjects, of Rights (December 2002)

172. David A. Weisbach, Taxation and Risk-Taking with Multiple Tax Rates (December 2002)

173. Douglas G. Baird and Robert K. Rasmussen, The End of Bankruptcy (December 2002) 
174. Richard A. Epstein, Into the Frying Pan: Standing and Privity under the Telecommunications Act of 1996 and Beyond (December 2002)

175. Douglas G. Baird, In Coase's Footsteps (January 2003)

176. David A. Weisbach, Measurement and Tax Depreciation Policy: The Case of Short-Term Assets (January 2003)

177. Randal C. Picker, Understanding Statutory Bundles: Does the Sherman Act Come with the 1996 Telecommunications Act? (January 2003)

178. Douglas Lichtman and Randal C. Picker, Entry Policy in Local Telecommunications: Iowa Utilities and Verizon (January 2003)

179. William Landes and Douglas Lichtman, Indirect Liability for Copyright Infringement: An Economic Perspective (February 2003)

180. Cass R. Sunstein, Moral Heuristics (March 2003)

181. Amitai Aviram, Regulation by Networks (March 2003)

182. Richard A. Epstein, Class Actions: Aggregation, Amplification and Distortion (April 2003)

183. Richard A. Epstein, The "Necessary" History of Property and Liberty (April 2003)

184. Eric A. Posner, Transfer Regulations and Cost-Effectiveness Analysis (April 2003)

185. Cass R. Sunstein and Richard H. Thaler, Libertarian Paternalizm Is Not an Oxymoron (May 2003)

186. Alan O. Sykes, The Economics of WTO Rules on Subsidies and Countervailing Measures (May 2003)

187. Alan O. Sykes, The Safeguards Mess: A Critique of WTO Jurisprudence (May 2003)

188. Alan O. Sykes, International Trade and Human Rights: An Economic Perspective (May 2003)

189. Saul Levmore and Kyle Logue, Insuring against Terrorism - and Crime (June 2003)

190. Richard A. Epstein, Trade Secrets as Private Property: Their Constitutional Protection (June 2003)

191. Cass R. Sunstein, Lives, Life-Years, and Willingness to Pay (June 2003)

192. Amitai Aviram, The Paradox of Spontaneous Formation of Private Legal Systems (July 2003)

193. Robert Cooter and Ariel Porat, Decreasing Liability Contracts (July 2003)

194. David A. Weisbach and Jacob Nussim, The Integration of Tax and Spending Programs (September 2003)

195. William L. Meadow, Anthony Bell, and Cass R. Sunstein, Statistics, Not Memories: What Was the Standard of Care for Administering Antenatal Steroids to Women in Preterm Labor between 1985 and 2000? (September 2003)

196. Cass R. Sunstein, What Did Lawrence Hold? Of Autonomy, Desuetude, Sexuality, and Marriage (September 2003)

197. Randal C. Picker, The Digital Video Recorder: Unbundling Advertising and Content (September 2003) 
198. Cass R. Sunstein, David Schkade, and Lisa Michelle Ellman, Ideological Voting on Federal Courts of Appeals: A Preliminary Investigation (September 2003) 